Article

\title{
Evaluation of Commercial Myxomatosis Vaccines against Recombinant Myxoma Virus (ha-MYXV) in Iberian Hare and Wild Rabbit
}

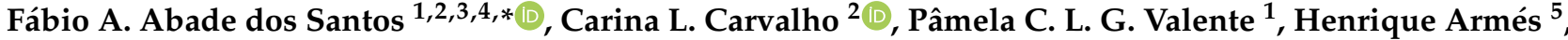 \\ Sylvia S. Reemers ${ }^{6}$, Maria C. Peleteiro ${ }^{1}$, Inés Calonge Sanz ${ }^{3}$, Kevin P. Dalton ${ }^{3}{ }^{\mathbb{D}}$, Francisco Parra ${ }^{3} \mathbb{D}$ \\ and Margarida D. Duarte ${ }^{1,2,4}$
}

Citation: Abade dos Santos, F.A.; Carvalho, C.L.; Valente, P.C.L.G.; Armés, H.; Reemers, S.S.; Peleteiro, M.C.; Calonge Sanz, I.; Dalton, K.P.; Parra, F.; Duarte, M.D. Evaluation of Commercial Myxomatosis Vaccines against Recombinant Myxoma Virus (ha-MYXV) in Iberian Hare and Wild Rabbit. Vaccines 2022, 10, 356.

https://doi.org/10.3390/

vaccines 10030356

Academic Editor: Kim Halpin

Received: 20 January 2022

Accepted: 22 February 2022

Published: 24 February 2022

Publisher's Note: MDPI stays neutral with regard to jurisdictional claims in published maps and institutional affiliations.

Copyright: (C) 2022 by the authors. Licensee MDPI, Basel, Switzerland. This article is an open access article distributed under the terms and conditions of the Creative Commons Attribution (CC BY) license (https:// creativecommons.org/licenses/by/ $4.0 /)$.
1 Centre for Interdisciplinary Research in Animal Health (CIISA), Faculdade de Medicina Veterinária, Universidade de Lisboa, Avenida da Universidade Técnica, 1300-477 Lisbon, Portugal; pamppam6@hotmail.com (P.C.L.G.V.); mcpelet@fmv.ulisboa.pt (M.C.P.); margarida.duarte@iniav.pt (M.D.D.)

2 Instituto Nacional de Investigação Agrária e Veterinária (INIAV, I.P.), Av. da República, Quinta do Marquês, 2780-157 Oeiras, Portugal; carina.carvalho@iniav.pt

3 Instituto Universitario de Biotecnología de Asturias (IUBA), Departamento de Bioquímica y Biología Molecular, Universidad de Oviedo, 33006 Oviedo, Spain; uo280761@uniovi.es (I.C.S.); daltonkevin@uniovi.es (K.P.D.); fparra@uniovi.es (F.P.)

4 Associate Laboratory for Animal and Veterinary Sciences (AL4AnimalS), 1300-477 Lisbon, Portugal

5 Hospital Veterinário de São Bento, R. de São Bento 358a, 1200-822 Lisbon, Portugal; henrique.armes@veterinario.pt

6 MSD Animal Health, Wim de Körverstraat 35, 5831 AN Boxmeer, The Netherlands; sylvia.reemers@merck.com

* Correspondence: fabio.abade@iniav.pt

\begin{abstract}
The recent emergence of a new myxoma virus capable of causing disease in the Iberian hare (Lepus granatensis) has resulted in numerous outbreaks with high mortality leading to the reduction, or even the disappearance, of many local populations of this wild species in the Iberian Peninsula. Currently, the available vaccines that prevent myxomatosis in domestic rabbits caused by classic strains of myxoma virus have not been assessed for use in Iberian hares. The main objective of this study was to evaluate the efficacy of commercial rabbit vaccines in Iberian hares and wild rabbits against the natural recombinant myxoma virus (ha-MYXV), bearing in mind its application in specific scenarios where capture is possible, such as genetic reserves. The study used a limited number of animals (pilot study), 15 Iberian hares and 10 wild rabbits. Hares were vaccinated with MixohipraFSA vaccine (Hipra) and Mixohipra-H vaccine (Hipra) using two different doses, and rabbits were vaccinated with the Mixohipra-H vaccine or the Nobivac Myxo-RHD PLUS (MSD Animal Health) using the recommended doses for domestic rabbits. After the vaccination trials, the animals were challenged with a wild type strain of ha-MYXV. The results showed that no protection to ha-MYXV challenge was afforded when a commercial dose of Mixohipra-FSA or Mixohipra-H vaccine was used in hares. However, the application of a higher dose of Mixohipra-FSA vaccine may induce protection and could possibly be used to counteract the accelerated decrease of wild hare populations due to ha-MYXV emergence. The two commercial vaccines (Mixohipra-H and Nobivac Myxo-RHD PLUS) tested in wild rabbits were fully protective against ha-MYXV infection. This knowledge gives more insights into ha-MYXV management in hares and rabbits and emphasises the importance of developing a vaccine capable of protecting wild populations of Iberian hare and wild rabbit towards MYXV and ha-MYXV strains.
\end{abstract}

Keywords: myxomatosis; Iberian hare; European wild rabbit; vaccines; ha-MYXV 


\section{Introduction}

In 2018, a natural recombinant myxoma virus (referred to as ha-MYXV or MYXVTol08/18) emerged in the Iberian hare (Lepus granatensis), affecting many populations in Spain [1,2] and Portugal [3-5].

With an apparent mortality rate of 55.4\% [6], the geographic spread of ha-MYXV outbreaks increased concerns about the resilience limit of the Iberian hare wild populations against the many insidious factors that have accelerated their decline over the last decades [5]. Despite the conservation status of the Iberian hare (Lepus granatensis) being considered of "Least Concern" by the IUCN in 2019, many local populations are currently threatened, as a result of severe loss of habitat imposed by human activities, and more recently, due to the emergence of infectious diseases such as ha-MYXV and LeHV-5 [2-5] and the cumulative effects with other diseases such as cysticercosis [5].

Although ha-MYXV was initially detected only in Iberian hares, it was later (mid-2020) reported in wild and domestic rabbits $[7,8]$. The recognition that ha-MYXV affects not only hares, but also the European rabbit (Oryctolagus cuniculus), questions the efficacy of crossprotection conferred by classic field strains of MYXV that circulate in wild rabbits. Likewise, the effectiveness of the commercial vaccines developed to protect domestic rabbits against classic myxoma strains is still unknown with regard to infection with ha-MYXV.

The susceptibility of the European rabbit to ha-MYXV also escalated the previous concerns that in 2019 gave the wild European rabbit (Oryctolagus cuniculus), for the first time in history, the status of "Endangered of Extinction", by the IUCN $[9,10]$.

Several strategies have been attempted to protect and recover the native wild rabbit populations for conservation and hunting purposes, such as captive breeding, reintroduction, restocking programs and vaccination campaigns, reviewed in [11].

This analysis constitutes a pilot study using a small number of wild animals to assess the commercial vaccines Mixohipra-FSA and Mixohipra- $\mathrm{H}$ as prophylactic tools to protect Iberian hare against ha-MYXV, bearing in mind its use in captive populations. The present study also evaluated the protection conferred by commercial vaccines Mixohipra- $\mathrm{H}$ and Nobivac Myxo-RHD PLUS against ha-MYXV in wild European rabbit. The possibility of using these vaccines as prophylactic tools in wild leporids whenever possible may be crucial to ensure the preservation of the genetic viability of the species in Portugal and Spain, particularly in case of an aggravation of the actual sanitary situation. This study also intends to test the susceptibility of wild rabbit to ha-MYXV isolated from the Iberian hare.

This study puts into practice the Measure 7.6 of Project + Coelho 2, entitled "Evaluation of the efficacy of commercial vaccines against myxomatosis in Iberian hare", identified within the National Plan for the control of Rabbit Haemorrhagic Disease 2 in rabbits (Dispatch 4757/17, 31 may ordered by the Minister of Agriculture), as it is vital to test all available resources in the fight against this emergent virus. This study, therefore, constitutes a pivotal step by assessing the potential of commercially available vaccines for the protection of wild Iberian hare and European rabbit.

\section{Materials and Methods}

\subsection{Origin of Animals and Pre-Adaptation to Captivity Conditions}

The main study (study 1) used nine 9-month-old, MYXV antibody seronegative, male hares (Lepus granatensis) randomly divided into 3 groups. These animals were the first generation born in captivity and were maintained in semi-extensive conditions for the sole purpose of this study. Their progenitors were captured in South Portugal between 31 August 2019 and 9 January 2020. Capture and accommodation of the hares were approved by the Institute for the Conservation of Nature and Forests (ICNF, I.P.), the Portuguese National Authority for Nature Conservation. A MYXV-seropositive, two-year old adult male hare, was used as control of the natural humoral response efficacy against the ha-MYXV.

A total of 10 wild rabbits (Oryctolagus cuniculus algirus), 6 months of age, seronegative for antibodies against MYXV were used in this study (study 2). The animals were obtained 
from a wild rabbit reproduction farm, where they were kept in captivity under extensive farming (approved by the National Authority (ICNF, I.P.).

Separately (study 3), after the conclusion of studies 1 and 2, an additional group of five 5-month-old hares, MYXV-seronegative, born in captivity after the start of the first trial, 3 females (\#013, \#014 and \#020) and 2 males (\#021 and \#025), were used to further confirm the results obtained in study 1 .

To avoid the effects of captivity stress on the immune response triggered by vaccination, the animals were adapted through a 40-day quarantine in specifically designed and constructed cages (structure description available upon request). These species-specific cages had different dimensions and particularities to allow the expression of natural hare behaviour (grooming, station position, etc.) as much as possible, to minimize injuries and to allow safe handling during the introduction and removal of the animal from the cage. The hare cages included an additional closed, opaque, confined space, to provide refuge and allow the animals to remain quiet.

A subjective rating of the animals' behaviour was scaled from 1 to 3 . A rating of 1 indicates a reduced reluctance to handling and sample collection, a rating of 2 indicates a reluctance to initial handling but an absence of sudden movements and a rating of 3 indicates reluctance throughout the entire procedure with many sudden movements.

The animals were observed daily for food, water intake and behaviour through uninterrupted monitoring cameras to assess the signs of disease or stress. The rabbit watering and feeding system did not allow the individual quantitative analysis of drinking water and daily food intake. The animals were acquainted with the staff (4 veterinarians) that carried out the trial. All the animals were subjected to hemogram and biochemical tests, faecal and blood parasite analyses before the study. The animals were considered fit for study when no signs of stress such as weight loss or signs of illness were observed and normal behaviour was maintained.

\subsection{Vaccines}

Three commercial vaccines against myxomatosis were used: (i) Mixohipra-FSA (HIPRA Headquarters, Amer, Girona, Spain; lot 12M9J), a live heterologous attapulgite adjuvanted vaccine containing Shope fibroma virus; (ii) Mixohipra-H (HIPRA Headquarters, Amer, Girona, Spain; lot 05D7G), a live homologous vaccine containing attenuated myxoma virus; (iii) Nobivac Myxo-RHD PLUS (MSD Animal Health, Boxmeer, The Netherlands; lot A003B02), a live homologous vector vaccine containing two attenuated recombinant myxoma virus vectors expressing the VP60 gene of RHDV or RHDV2 [12].

The investigational veterinary products (IVP) were used within the stated shelf-life.

\subsection{Experimental Design}

The hares of study 1 were randomly divided into four groups and identified with an earring according to the following:

(i) H-G1: a negative control group of three animals (\#231, \#232 and \#233), MYXV seronegative and non-vaccinated;

(ii) H-G2: a group of three animals (\#076, \#077 and \#078), MYXV seronegative, vaccinated with a $2.90 \times 10^{4} \mathrm{ffu}$ (focus-forming units) dose of Mixohipra-FSA vaccine at the start of the study and 21 days later with a $1.95 \times 10^{4} \mathrm{ffu}$ dose of Mixohipra-H vaccine;

(iii) H-G3: a group of three animals (\#042, \#043 and \#044), MYXV seronegative, vaccinated with a $2.90 \times 10^{5} \mathrm{ffu}$ dose of Mixohipra-FSA vaccine at the start of the study and 21 days later a $1.95 \times 10^{5}$ dose of Mixohipra-H vaccine;

(iv) H-G4: a positive control animal (\#10), MYXV seropositive, collected from the field after natural recovery from myxomatosis.

The wild rabbits (study 2) were randomly divided into three groups and identified with an earring according to the following: 
(i) R-G1: a negative control group of four animals (\#449, \#451, \#000 and \#001), MYXV seronegative and non-vaccinated;

(ii) R-G2: a group of three animals (\#442, \#444 and \#445), MYXV seronegative, vaccinated with a $1.95 \times 10^{4} \mathrm{ffu}$ dose of Mixohipra-H vaccine at the start of the study;

(iii) R-G3: a group of three animals (\#446, \#447 and \#448), MYXV seronegative, vaccinated with a single dose of Nobivac Myxo-RHD PLUS vaccine $\left(10^{3.0}-10^{5.8} \mathrm{ffu}\right.$ of each two vectors) at the start of the study.

A schematic overview of the trials is depicted in Figure 1. The vaccines were inoculated subcutaneously (s.c.) with the volume of the vaccine distributed in two different places in the dorsal cervical area. At the time of vaccination, the groups of non-vaccinated animals (\#H-G1, H-G4 and R-G1) were inoculated s.c. with $1 \mathrm{~mL}$ of sterile phosphate-buffered saline (PBS) $\mathrm{pH} 7.2$.

The additional group of five 5-month-old hares (study 3 ) was vaccinated as group $\mathrm{H}-\mathrm{G} 3$, with an infectious dose of $2.90 \times 10^{5} \mathrm{ffu}$ of Mixohipra-FSA vaccine and 21 days later revaccinated with Mixohipra-FSA vaccine with the same infectious dose $\left(2.90 \times 10^{5} \mathrm{ffu}\right)$.

The hare and rabbit experimental trials were carried out separately. Between experiments, the installations were cleaned and disinfected, submitted to $24 \mathrm{~h}$ of UVC irradiation, and subjected to a 60-day sanitary vacuum. During these two trials, blood samples were collected from all animals according to the protocol represented in Figure 1. At the time of sampling, body weight, respiratory rate and rectal temperature were also monitored.

Hares

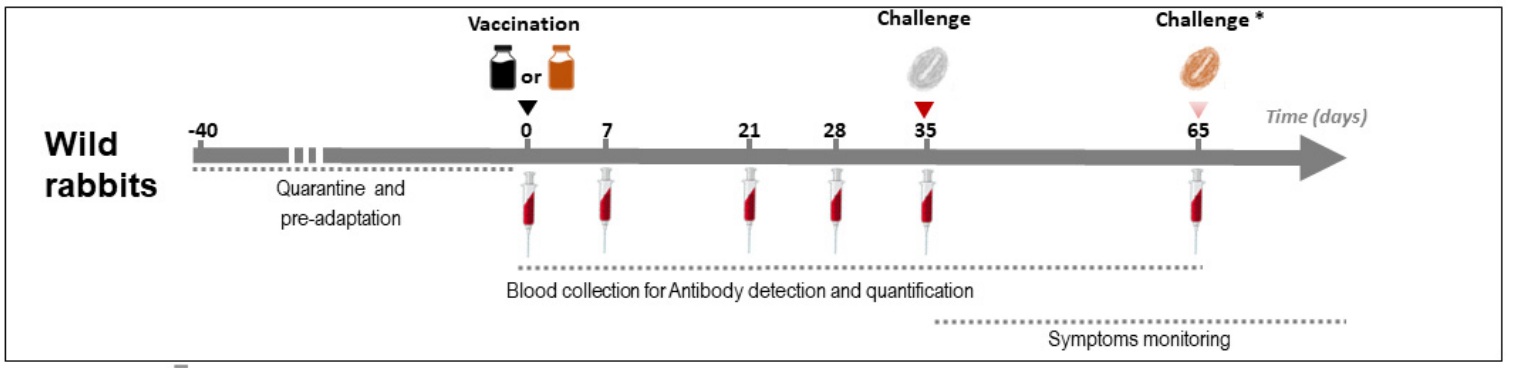

Shope Fibroma Virus Vaccine (Mixohipra-FSA)

Myxoma Virus Vaccine (Mixohipra-H)

Myxo-RHDPLUS

Live Myxoma Virus (ha-MYXV from hare)

Live MyxomaVirus (ha-MYXV from wild rabbit)

Figure 1. Schematic representation of the vaccination and sampling schedule performed on hares and rabbits (Studies 1 and 2). * The second challenge was only carried out on part of the animals (see Section 2.8).

\subsection{Sampling and Blood Analyses}

Given the nervous natural behaviour of wild leporids, wilder in the Iberian hare than in the wild rabbit, there is a high risk of self-injury during handling, especially affecting the lumbar spine following sudden movements in reaction to human presence or restraint. For this reason, the collection of samples was minimized to avoid the impact of stress on the results and to reduce the risk of harming the animals during the procedures. 
The animals were handled with slow but assertive movements without sedation or anaesthesia. Blood collections were performed according to the method described by [13], without midazolam administration to avoid the effects of recurrent sedation.

The volume of blood collected from hares and rabbits was $6 \mathrm{~mL}$ and $1 \mathrm{~mL}$, respectively. The blood was divided into three collection tubes, namely dry for serology, EDTA for hemogram and lithium heparin for biochemical analyses.

On the same day of sampling, serum was separated from the clot by centrifugation at $1000 \times g$ for $10 \mathrm{~min}$ at $4{ }^{\circ} \mathrm{C}$. The haematological analyses were performed automatically using the Procyte Dx haematological counter (IDEXX $\left.{ }^{\circledR}\right)$ with further manual correction. The haematocrit was confirmed and corrected by the evaluation of the microhematocrit tube.

The relative count of leukocytes and the search for haemoparasites were performed by microscopical examination (400-1000× magnification) of blood and buffy coat smears stained with Diff-Quik.

Biochemical analyses were performed in a Catalyst One Chemistry Analyzer (IDEXX, Westbrook, ME, USA) using the Chem 15 CLIP consumables. All the analyses were performed in duplicate.

\subsection{Serological Analyses}

Sera were analysed for MYXV antibodies using a commercial indirect ELISA (iELISA) (Civtest ${ }^{\circledR}$ Cuni Mixomatosis, Hipra, Girona, Spain), following the manufacturer's instructions. Positive and negative controls (rabbit sera, provided in the kit) and samples were tested in duplicate. Results were expressed as Relative Index 10 (RI10).

All sera were also analysed by an in house immunofluorescence test (IFT) [7] using the intervals previously described [12].

The titre of the immunofluorescence test was estimated using 4 replicates for each dilution. Some hare sera were additionally tested at the OIE International Reference Laboratory of Myxomatosis (IZLER, Brescia, Italy), using a competitive ELISA (cELISA).

The titre of the seroneutralization test was estimated using 2 replicates for each dilution (method available upon request). Briefly, sera were initially inactivated by incubation at $56{ }^{\circ} \mathrm{C}$ for $30 \mathrm{~min}$. Sera were then two-fold diluted from 1/4 to 1/2048 and incubated $2 \mathrm{~h}$ at $37^{\circ} \mathrm{C}$ with $100 \mathrm{ffu}$ of ha-MYXV (strain 20545PT20) using a 96-well plate. Then, $0.01 \times 10^{6}$ RK13 cells were sown in Gibco MEM medium (Thermo Fisher Scientific, Waltham, MA, USA) with 5\% heat-inactivated foetal bovine serum-FBS (Thermo Fisher Scientific, Waltham, MA, USA). Virus plaques were visualized after 5 days of incubation and the titre considered the mean of the last dilutions that inactivated $100 \%$ of the virus.

\subsection{Viruses}

Viral isolation of ha-MYXV from eyelid samples from an infected wild rabbit (20545PT20, found dead in July 2020, Portugal) and from an infected hare (38455PT18, found dead in November 2018 in Portugal) were carried out using Rabbit Kidney (RK13) cells (ATCCCCL-37). The rabbit and hare ha-MYXV strains were adapted to cell culture by seven passages, and then purified and titrated.

In detail, tissue samples were homogenised at 20\% $(w / v)$ in PBS containing penicillin, streptomycin and amphotericin B (antibiotic-antimycotic), used according to the manufacturer (Gibco, Waltham, MA, USA). Following centrifugation $(3000 \times g, 10 \mathrm{~min}$, $4{ }^{\circ} \mathrm{C}$ ), the supernatant was filtered through a $0.45-\mu \mathrm{m}$-pore-size filter (Millipore Express, Darmstad, Germany) and used to inoculate subconfluent (70\%) RK13 cells grown in Eagle's medium supplemented with 5\% FBS, penicillin, streptomycin and amphotericin B (antibiotic-antimycotic used at 1:100, Gibco) and $50 \mu \mathrm{g} / \mathrm{mL}$ gentamicin (Gibco). Cells were maintained at $37{ }^{\circ} \mathrm{C}$ in a humidified atmosphere with $5 \% \mathrm{CO} 2$ and observed daily for cytopathic effect (CPE) by phase-contrast microscopy. Virus isolation was confirmed by an in-house IFT using MYXV positive hare serum [7]. Virus isolates were named 20545PT20 and 38455PT18, according to the identification of origin, and used for the immunofluorescence tests and seroneutralization assays. 
Unlike the virus used in the IFT, produced as described above, the viruses used in challenge experiments were not subjected to cell culture passages to avoid mutations and recombination events during in vitro culturing, and correspond to the same isolates (20545PT20 and 38455PT18). The oedematous eyelids removed from these animals were washed seven times with sterile PBS pH 7.2 with mechanical agitation, to remove external tissue contaminants resulting from the accumulation of purulent material during the illness. After initial scalpel blade fragmentation, a $10 \%(w / v)$ tissue homogenate was prepared in sterile PBS pH 7.2, by mechanical maceration with $0.5 \mathrm{~mm}$ zirconia beads using four cycles of $15 \mathrm{~s}$ at $3000 \mathrm{rpm}$ with an interval of $10 \mathrm{~s}$ (Precellys ${ }^{\circledR}$ Evolution). Before and after the process, the macerates were kept on ice.

After this initial process, the viruses were purified by centrifugation using a $36 \%$ sucrose cushion and then using a $24-40 \%$ sucrose step gradient [14]. The dilutions of the virus stock for the challenge were performed using sterile PBS pH 7.2. The final batch (corresponding to the dilution inoculated into the animals) was filtered using $0.45 \mu \mathrm{m}$ pore filters and a sample submitted to incubation in blood agar, TSA-Tryptic Soy Agar and Sahoraud's dextrose agar, targeted to fungal agents according to routine methodology, to confirm the absence of contamination.

For stock titration, the virus was diluted in MEM (10-1 to 10-9) and adsorbed to 70\% confluent RK13 cells, for $1 \mathrm{~h}$ at $37^{\circ} \mathrm{C}$. After 5 days of incubation, plates were washed with PBS and fixed with 70\% Acetone (Scharlab, Barcelone, Spain), for $15 \mathrm{~min}$ at room temperature. Then, the wells were washed with PBS and stained with $0.4 \%$ crystal violet (SigmaAldrich, St. Louis, MO, USA), and visualized using an inverted microscope. The titre was estimated using 4 replicates for each dilution according to a published method [15]. The ha-MYXV stocks were then diluted in sterile PBS pH 7.2 to a concentration of $100 \mathrm{ffu} / \mathrm{mL}$ (focus-forming units per millilitre).

A similar method was used to titrate the vaccine stock (only for Mixohipra vaccines), using $100 \mu \mathrm{L}$ of reconstituted vaccine to infect 70\% confluent RK13 cells in 48-well plates. The reconstituted vaccine was 10 -fold diluted using MEM until $10^{-6}$. The vaccine virus was adsorbed for $1 \mathrm{~h}$ at $37^{\circ} \mathrm{C}$, and the titre was calculated after 5 days of incubation according to the previously described method [15].

\subsection{Virus Detection by $q P C R$}

Detection of ha-MYXV DNA by qPCR was used to confirm the isolation in RK13 cells [16]. The same molecular method was used to investigate the presence of the virus in faeces of the animals after vaccination and challenge, in tissues from the animals that died during the experiment, as well as in the drinking water. The presence of LeHV-5 was also analysed [4,17].

For nucleic acid extraction, cell supernatants or water samples were used directly for extraction, without dilution. Faeces or fresh samples of liver and spleen, kidney, lung, eyelid and genitalia were homogenised at $20 \%(w / v)$ with PBS and clarified at $3000 \mathrm{~g}$ for $5 \mathrm{~min}$ at $4{ }^{\circ} \mathrm{C}$. Total DNA and RNA were extracted from $200 \mu \mathrm{L}$ of the clarified supernatants, using the MagAttract 96 cador Pathogen Kit (Qiagen, Hilden, Germany) in a BioSprint 96 nucleic acid extractor (Qiagen, Hilden, Germany), according to the manufacturer's protocol.

Amplification reactions were performed in a Bio-Rad CFX96 ${ }^{\mathrm{TM}}$ Thermal Cycler (BioRad Laboratories Srl, Redmond, WA, USA), using the Multiplex PCR NZYTaq $2 \times$ Colourless Master Mix (NZYTech, Lisbon, Portugal).

\subsection{Challenge}

Hares (groups H-G1, HG-2, HG-3 and H-G4) were challenged at day 72 with the isolate ha-MYXV 38455PT18. Challenge of hares was carried out by inoculating $1 \mathrm{~mL}$ of the virus suspension subcutaneously (100 ffu/mL of ha-MXYV, diluted in sterile PBS pH 7.2), corresponding to the maximum estimated viral load delivered by arthropod vectors in nature [18]. In case of failure to develop disease and humoral response, hares were re- 
inoculated with $1 \mathrm{~mL}$ of $1000 \mathrm{ffu} / \mathrm{mL}$ (ha-MXYV, isolate 38455PT18) at day 102 (Figure 1). Hares of study 3 were not submitted to challenge.

Wild rabbits (half of group R-G1 and groups R-G2 and R-G3) were challenged at day 35 with the isolate ha-MYXV 20545PT20 (Figure 1). Two of the negative controls (from R-G1, $\# 000$ and \#001) were kept separately and were not inoculated. Thirty days later (day 65), these two rabbits were inoculated with the isolate ha-MYXV 38455PT18, the same used in the hare's assay. The rabbits challenge was performed with $1 \mathrm{~mL}$ of a $1000 \mathrm{ffu} / \mathrm{mLdiluted}$ in sterile PBS pH 7.2, inoculated subcutaneously, given the failure to induce disease in two hares when inoculated with $1 \mathrm{~mL}$ of a $100 \mathrm{ffu} / \mathrm{mL}$ virus dilution, as discussed below.

\subsection{Clinical Signs Monitoring}

During the vaccination trial and after challenge, the animals were continuously monitored by cameras, using black light for night vision. Daily visits to the installations by a veterinarian complemented surveillance. The cages allowed us to observe the animals without handling and to photograph the evolution of clinical signs. The cages also allowed us to touch the animals without the need to hold them, allowing us to assess the health and nutritional status as well as the presence of inflammatory lesions, for example at the site of vaccine inoculation, without disturbing the animals.

To follow the evolution of clinical signs after challenge, the animals' eyes were photographed daily. The hares' genitals were not monitored daily to minimize stress and risk of injuries, given the need to handle the animals. However, the daily monitoring of genitals in rabbits was carried out given their easier behaviour and due to the cage characteristics.

Sequential photographs of eyelid oedema were evaluated for each animal and subjectively classified (very mild, mild, moderate and marked). The palpebral fissure height was estimated and divided into four different categories $(<25 \%, 25-50 \%, 50-75 \%$ and $>75 \%)$.

\subsection{Necropsy and Histopathology}

Necropsy was performed according to routine procedures, and samples were collected for bacteriology (liver, spleen and lung), parasitology (gastrointestinal tract and liver), histopathology (lung, liver, spleen, kidney, eyelid and genitalia) and virology (liver, spleen, lung, kidney, eyelid, lip, urine, seminal vesicle, brain, bone marrow, spinal cord and genitalia) analyses, following the routine procedures. For histopathology, the fragments were fixated in $10 \%$ neutral buffered formalin $(w / v)$, routinely paraffin-embedded, sectioned at $4 \mu \mathrm{m}$, and stained with Hematoxylin and Eosin (H\&E).

\subsection{Ethical and Legal Framework}

The study was carried out in line with the measures identified in the National Plan for the control of rabbit haemorrhagic disease 2 (Dispatch 4757/2017, 31 May), operated through Project +Coelho 2, and approved by the National Authority for Animal Health (DGAV, Nr 79/ECVPT / 20145) according to the National legislation (Decree-Law No. 113/2013, 7 August) after a positive declaration from the independent Advisory Body Responsible for Animal Welfare (ORBEA-INIAV, I.P.).

The Iberian hare specimens used in the experiment were from a pilot genetic reserve, established in 2019 within the scope of the +Coelho 2 Project, approved by ICNF. The Iberian hare founder population was captured in the field through events authorized by ICNF for the current proposal. The 14 hares selected for the study constitute the first generation born in captivity. The seropositive hare (\#10) was captured in the field in October 2019. All wild rabbits used in this study were purchased from a certified wild rabbit captivity centre complying with the Portuguese legislation. Vaccination and challenge were conducted in a BSL-2 mobile unit belonging to INIAV I.P.

Taking into account the $3 \mathrm{R}$ policy, all steps of this assay that could be performed in vitro were maximized (replacement) (e.g., isolation, virus multiplication), reducing the number of animals to the minimum likely to give results for a pilot study (reduction) and all manipulation techniques, data analysis and maintenance of the animals, were thought 
and designed specifically (refinement) for the Iberian hare and wild rabbit (e.g., BSL-2 built specifically for the study, specific cages were built and adapted to the needs of these two species. To minimize stress and self-inflicted damage, the animals were always handled by the same people and kept in a calm environment, etc.)

\section{Results}

The data described below refer to the quarantine and vaccination periods (from day -40 to day 72 in the hare trial and until day 35 in the rabbits' trial), i.e., before the challenge. Surveillance through day and night viewing cameras revealed an adequate adaptation to cages, expression of natural behaviour (Figure 2) and maintenance of water and food ingestion within the normal range.
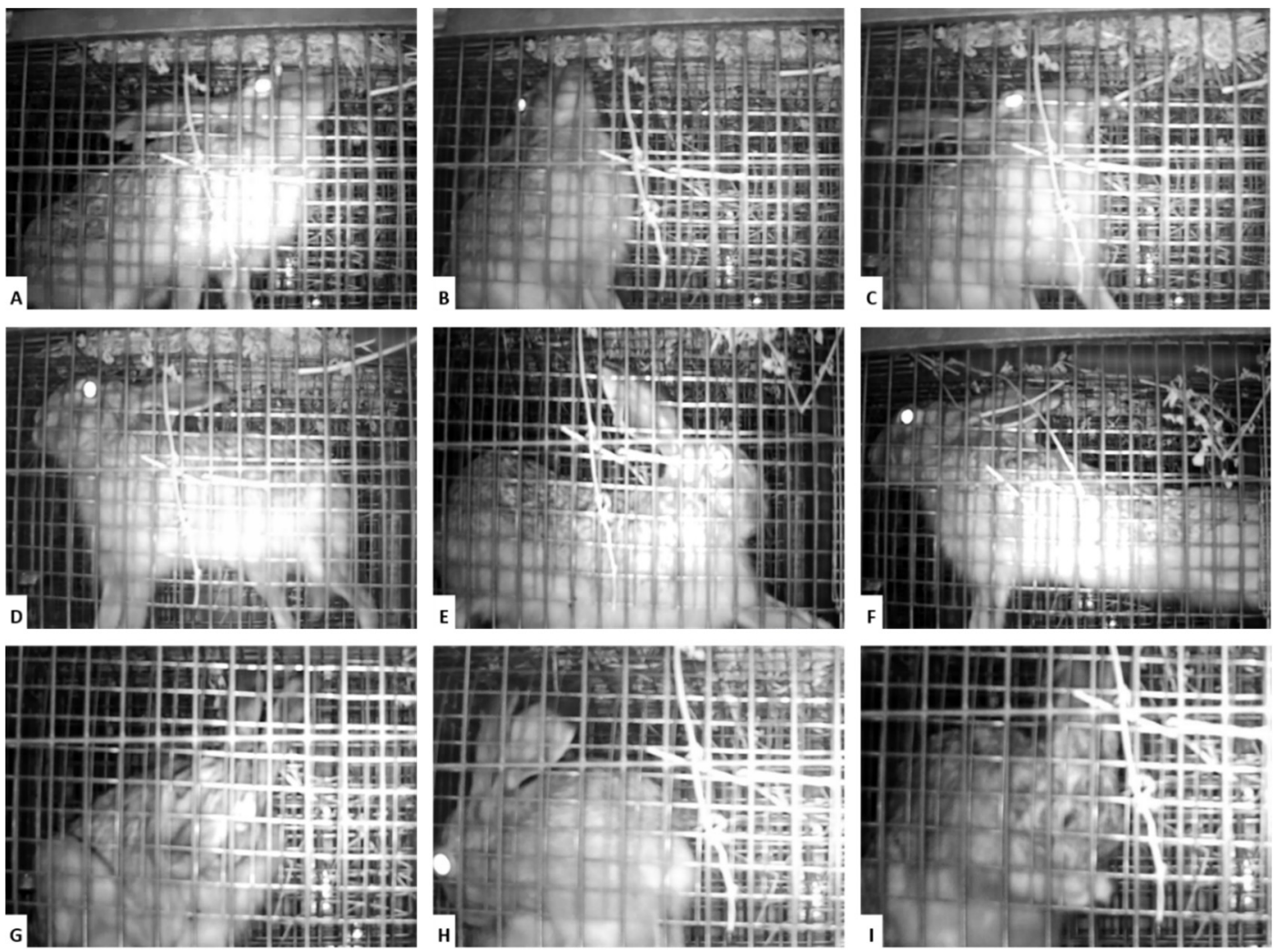

Figure 2. Pictures from the continuous monitoring performed by backlight cameras. The cages were designed to provide cognitive enrichment, making the access to alfalfa hay difficult (A-C), to allow all the hare's natural positions, namely muscle stretching (D-F). Animal welfare can be observed, among other factors, by the presence of grooming, which is very common in this species (G-I).

The 10 hares entered study 1 with an average weight of $1.90 \pm 0.26 \mathrm{~kg}$. All weight measurements were carried out in the morning, at approximately the same time. The maximum loss of weight before the challenge was $5.55 \%$. Behaviour was stable throughout the entire experiment, with only a slight deterioration over the number of handlings, starting with an average rating of 1.3 in the first sampling and ending with 2.1 in the last one (after seven sampling procedures). The average respiratory frequency after the initial containment was $87 \pm 13$ breaths per minute (bpm) at the moment of first sampling and of $108 \pm 9 \mathrm{bpm}$ at the moment of the last sampling. The temperature was also measured in all sampling moments, showing an average of $39.5 \pm 0.4{ }^{\circ} \mathrm{C}$.

The rabbits did not have any remarkable loss in weight; on the contrary, they gained weight throughout the experiment (an average of $10.3 \%$ ), the mean weight before the challenge being $1.12 \pm 0.27 \mathrm{~kg}$. The rabbits had an average temperature of $39.05 \pm 0.1{ }^{\circ} \mathrm{C}$ in the five moments of blood sampling and a mean breath rate of $58 \pm 23 \mathrm{bpm}$. The behaviour 
of rabbits was substantially more favourable compared to hares, starting with an average rating of 1 in the first sampling and ending with 1.2 in the last (after five sampling events). In both species, the variations in weight, respiratory rate and rectal temperature were considered physiological, since the start of the study until the start of the challenge.

\subsection{Humoral Immune Response to Vaccination}

In general, the hares vaccinated with the lower dose of the two Mixohipra vaccines (H-G2), did not produce a serological response, except for hare \#077, which achieved an RI10 title of 2.81. However, this hare died suddenly on day 51, hampering the follow-up of the next phases of the experiment. Necropsy showed that the cause of death of hare \#077 was dysbiosis, probably due to stress, the animal being in good body condition.

Two of the three hares vaccinated with the higher dose of the two Mixohipra vaccines (H-G3), seroconverted, achieving an RI10 value of 5.8 (hare \#043) and 7.1 (hare \#044) by day 72 of the trial. Hare \#042 showed no seroconversion during the experiment. The increase in serological response was higher after inoculation with the Mixohipra-FSA vaccine, namely between day 0 to day 21 . The increase in serological response after boost vaccination with Mixohipra-H vaccine, between day 21 and day 42, was much lower or even absent (Table 1). By day 21, hares \#043 and \#044 registered a titre of 10 and 20, respectively, in the cELISA, while all the other hares remained negative. These titres remained unchanged, even after the boost vaccination.

These results were further confirmed in study 3 , with all the five hares seroconverting. At day 0 , the RI10 was $<1.0$ in the five animals and 21 days later was $4.6,4.9,3.7,8.2$ and 4.9 for hares \#013,\#014,\#020,\#021 and \#025, respectively. Twenty-one days after the second vaccination, the RI10 values obtained with the iELISA were 6.7, 6.6, 7.5, 11.2 and 5.4, respectively. Contrary to animals \#043 and \#044 (H-G3), which were boosted with Mixohipra-H, the administration of a boost with Mixohipra-FSA had a positive effect on the antibody titres.

As expected, the animals from the unvaccinated control group (H-G1) did not seroconvert (Table 1).

Rabbits \#448, \#446, and \#447, vaccinated with Myxo-RHD PLUS (R-G3) seroconverted and on day 35 achieved an RI10 titre of 2.1, 4.8, and 5.4, respectively (Table 2). Rabbits \#444, $\# 445$, and \#442, vaccinated with Mixohipra-H (R-G2) seroconverted and on day 35 achieved an RI10 titre of 1.72, 2.15 and 4.11, respectively. As expected, none of the animals from the non-vaccinated group, R-G1 (\#449, \# 451, \#000 and \#001) developed anti-MYXV antibodies.

Table 1. Serological responses of hares (study 1) after vaccination and before challenge. Data were measured by indirect ELISA (RI10), immunofluorescence titration (IFT = titre in log2) and seroneutralization $(\mathrm{SNT}=$ titre$)$.

\begin{tabular}{|c|c|c|c|c|c|c|c|c|c|c|}
\hline \multirow[b]{2}{*}{ Group } & \multirow[b]{2}{*}{ Hare ID } & \multirow[b]{2}{*}{ Vaccine } & \multirow[b]{2}{*}{ Technique } & \multicolumn{7}{|c|}{ Humoral Response } \\
\hline & & & & Day 0 & Day 7 & Day 21 & Vaccine & Day 28 & Day 42 & Day 72 \\
\hline \multirow{9}{*}{ H-G1 } & & & iELISA & 0.5 & 0.23 & 0.16 & \multirow{3}{*}{ Not vac } & 0.13 & 0.19 & 0.23 \\
\hline & \#231 & Not vac & IFT & $<2$ & $<2$ & $<2$ & & $<2$ & $<2$ & $<2$ \\
\hline & & & SNT & $<1 / 4$ & $<1 / 4$ & $<1 / 4$ & & $<1 / 4$ & $<1 / 4$ & $<1 / 4$ \\
\hline & & & iELISA & 0.35 & 0.16 & 0.39 & \multirow{3}{*}{ Not vac } & 0.29 & 0.15 & 0.28 \\
\hline & \#232 & Not vac & IFT & $<2$ & $<2$ & $<2$ & & $<2$ & $<2$ & $<2$ \\
\hline & & & SNT & $<1 / 4$ & $<1 / 4$ & $<1 / 4$ & & $<1 / 4$ & $<1 / 4$ & $<1 / 4$ \\
\hline & \multirow{3}{*}{ \#233 } & \multirow{3}{*}{ Not vac } & iELISA & 0.63 & 0.47 & 0.42 & \multirow{3}{*}{ Not vac } & 0.22 & 0.22 & 0.08 \\
\hline & & & IFT & $<2$ & $<2$ & $<2$ & & $<2$ & $<2$ & $<2$ \\
\hline & & & SNT & $<1 / 4$ & $<1 / 4$ & $<1 / 4$ & & $<1 / 4$ & $<1 / 4$ & $<1 / 4$ \\
\hline
\end{tabular}


Table 1. Cont.

\begin{tabular}{|c|c|c|c|c|c|c|c|c|c|c|}
\hline \multirow[b]{2}{*}{ Group } & \multirow[b]{2}{*}{ Hare ID } & \multirow[b]{2}{*}{ Vaccine } & \multirow[b]{2}{*}{ Technique } & \multicolumn{7}{|c|}{ Humoral Response } \\
\hline & & & & Day 0 & Day 7 & Day 21 & Vaccine & Day 28 & Day 42 & Day 72 \\
\hline \multirow{9}{*}{ H-G2 } & \multirow{3}{*}{ \#076 } & \multirow{3}{*}{$\begin{array}{c}1 \times \\
\text { M-FSA }\end{array}$} & iELISA & 0.9 & 1.01 & 0.84 & \multirow{3}{*}{$1 \times \mathrm{M}-\mathrm{H}$} & 0.59 & 0.59 & 0.18 \\
\hline & & & IFT & $<2$ & 3 & 3.5 & & 4 & 4 & 4 \\
\hline & & & SNT & $<1 / 4$ & $<1 / 4$ & $<1 / 4$ & & $<1 / 4$ & $<1 / 4$ & $<1 / 4$ \\
\hline & \multirow{3}{*}{ \#077 } & \multirow{3}{*}{$\begin{array}{c}1 \times \\
\text { M-FSA }\end{array}$} & iELISA & 0.31 & 0.81 & 1.55 & \multirow{3}{*}{$1 \times \mathrm{M}-\mathrm{H}$} & 2.45 & 2.81 & \multirow{3}{*}{ - } \\
\hline & & & IFT & $<2$ & $<2$ & 4 & & 4 & 5.5 & \\
\hline & & & SNT & $<1 / 4$ & $<1 / 4$ & $<1 / 4$ & & $1 / 8$ & $1 / 8$ & \\
\hline & \multirow{3}{*}{ \#078 } & \multirow{3}{*}{$\begin{array}{c}1 \times \\
\text { M-FSA }\end{array}$} & iELISA & 0.96 & 0.49 & 0.4 & \multirow{3}{*}{$1 \times \mathrm{M}-\mathrm{H}$} & 0.36 & 0.36 & 0.12 \\
\hline & & & IFT & $<2$ & $<2$ & 3 & & 3 & 3 & 3 \\
\hline & & & SNT & $<1 / 4$ & $<1 / 4$ & $<1 / 4$ & & $<1 / 4$ & $<1 / 4$ & $<1 / 4$ \\
\hline \multirow{9}{*}{ H-G3 } & \multirow{3}{*}{ \#042 } & \multirow{3}{*}{$\begin{array}{c}10 \times \\
\text { M-FSA }\end{array}$} & iELISA & 0.6 & 0.36 & 0.25 & \multirow{3}{*}{$10 \times \mathrm{M}-\mathrm{H}$} & 0.24 & 0.18 & 0.03 \\
\hline & & & IFT & $<2$ & $<2$ & 3 & & 3 & 3 & 3 \\
\hline & & & SNT & $<1 / 4$ & $<1 / 4$ & $<1 / 4$ & & $<1 / 4$ & $<1 / 4$ & $<1 / 4$ \\
\hline & \multirow{3}{*}{ \#043 } & \multirow{3}{*}{$\begin{array}{c}10 \times \\
\text { M-FSA }\end{array}$} & iELISA & 0.79 & 0.62 & 5.55 & \multirow{3}{*}{$10 \times \mathrm{M}-\mathrm{H}$} & 5.05 & 5.5 & 5.8 \\
\hline & & & IFT & $<2$ & 4.5 & 6.5 & & 7 & 7 & 7.5 \\
\hline & & & SNT & $<1 / 4$ & $<1 / 4$ & $1 / 16$ & & $1 / 16-1 / 32$ & $1 / 16-1 / 32$ & $1 / 16-1 / 32$ \\
\hline & \multirow{3}{*}{ \#044 } & \multirow{3}{*}{$\begin{array}{c}10 \times \\
\text { M-FSA }\end{array}$} & iELISA & 0.75 & 0.36 & 5.57 & \multirow{3}{*}{$10 \times \mathrm{M}-\mathrm{H}$} & 6.87 & 6.7 & 7.1 \\
\hline & & & IFT & $<2$ & 3.5 & 7 & & 7.5 & 7 & 8.5 \\
\hline & & & SNT & $<1 / 4$ & $<1 / 4$ & $1 / 16$ & & $1 / 16-1 / 32$ & $1 / 16-1 / 32$ & $1 / 16-1 / 32$ \\
\hline \multirow{3}{*}{$\mathrm{H}-\mathrm{G} 4$} & \multirow{3}{*}{$\# 10$} & \multirow{3}{*}{$\begin{array}{l}\text { Natural } \\
\text { immunity }\end{array}$} & iELISA & & & 7.09 & \multirow{3}{*}{$\begin{array}{l}\text { Natural } \\
\text { immunity }\end{array}$} & 7.1 & 7.19 & 7.28 \\
\hline & & & IFT & & & 9 & & 9 & 9 & 9 \\
\hline & & & SNT & & & $1 / 128$ & & $1 / 128$ & $1 / 128$ & $1 / 128$ \\
\hline
\end{tabular}

$1 \times$ M-FSA, vaccinated with $2.90 \times 10^{4} \mathrm{ffu}$ of Mixohipra-FSA; $10 \times$ M-FSA, vaccinated with $2.90 \times 10^{5} \mathrm{ffu}$ dose of Mixohipra-FSA; $1 \times \mathrm{M}-\mathrm{H}$, vaccinated with $1.95 \times 10^{4} \mathrm{ffu}$ dose of Mixohipra-H; $10 \times \mathrm{M}-\mathrm{H}$, vaccinated with $1.95 \times 10^{5} \mathrm{ffu}$ dose of Mixohipra-H; Not vac, not vaccinated.

Table 2. Serological responses of rabbits (study 2) after vaccination and before challenge. Data were measured by indirect ELISA (RI10), immunofluorescence titration (IFT = titre in log2) and seroneutralization $(\mathrm{SNT}=$ titre). RI10.

\begin{tabular}{|c|c|c|c|c|c|c|c|c|}
\hline \multirow[b]{2}{*}{ Group } & \multirow[b]{2}{*}{ Rabbits ID } & \multirow[b]{2}{*}{ Vaccine } & \multirow[b]{2}{*}{ Technique } & \multicolumn{5}{|c|}{ Humoral Response } \\
\hline & & & & Day 0 & Day 7 & Day 21 & Day 28 & Day 35 \\
\hline \multirow{12}{*}{ R-G1 } & \multirow{3}{*}{ \#449 } & \multirow{3}{*}{ Not vac } & iELISA & 0.05 & 0.06 & 0.07 & 0.06 & 0.02 \\
\hline & & & IFT & $<2$ & $<2$ & $<2$ & $<2$ & $<2$ \\
\hline & & & SNT & $<1 / 4$ & $<1 / 4$ & $<1 / 4$ & $<1 / 4$ & $<1 / 4$ \\
\hline & \multirow{3}{*}{$\# 451$} & \multirow{3}{*}{ Not vac } & iELISA & 0.22 & 0.01 & 0.1 & 0.27 & 0.2 \\
\hline & & & IFT & $<2$ & $<2$ & $<2$ & $<2$ & $<2$ \\
\hline & & & SNT & $<1 / 4$ & $<1 / 4$ & $<1 / 4$ & $<1 / 4$ & $<1 / 4$ \\
\hline & \multirow{3}{*}{$\# 000$} & \multirow{3}{*}{ Not vac } & iELISA & 0.13 & 0.09 & 0.15 & 0.18 & 0.31 \\
\hline & & & IFT & $<2$ & $<2$ & $<2$ & $<2$ & $<2$ \\
\hline & & & SNT & $<1 / 4$ & $<1 / 4$ & $<1 / 4$ & $<1 / 4$ & $<1 / 4$ \\
\hline & \multirow{3}{*}{ \#001 } & \multirow{3}{*}{ Not vac } & iELISA & 0.32 & 0.27 & 0.38 & 0.21 & 0.14 \\
\hline & & & IFT & $<2$ & $<2$ & $<2$ & $<2$ & $<2$ \\
\hline & & & SNT & $<1 / 4$ & $<1 / 4$ & $<1 / 4$ & $<1 / 4$ & $<1 / 4$ \\
\hline \multirow{9}{*}{ R-G2 } & \multirow{3}{*}{$\# 442$} & \multirow{3}{*}{$1 \times \mathrm{M}-\mathrm{H}$} & iELISA & 0.01 & 0.05 & 1.79 & 2.33 & 4.11 \\
\hline & & & IFT & $<2$ & 4 & 6 & 7.5 & 9 \\
\hline & & & SNT & $<1 / 4$ & $<1 / 4$ & $<1 / 4$ & $1 / 8$ & $1 / 32$ \\
\hline & \multirow{3}{*}{ \#444 } & \multirow{3}{*}{$1 \times \mathrm{M}-\mathrm{H}$} & iELISA & 0.04 & 0.18 & 1.1 & 1.04 & 1.72 \\
\hline & & & IFT & $<2$ & 2 & 5.5 & 6 & 7 \\
\hline & & & SNT & $<1 / 4$ & $<1 / 4$ & $<1 / 4$ & $1 / 4$ & $1 / 8$ \\
\hline & \multirow{3}{*}{$\# 445$} & \multirow{3}{*}{$1 \times \mathrm{M}-\mathrm{H}$} & iELISA & 0.1 & 0.29 & 0.83 & 1.04 & 2.15 \\
\hline & & & IFT & $<2$ & 3 & $<2$ & 6 & 8.5 \\
\hline & & & SNT & $<1 / 4$ & $<1 / 4$ & $<1 / 4$ & $1 / 4$ & $1 / 8$ \\
\hline
\end{tabular}


Table 2. Cont.

\begin{tabular}{|c|c|c|c|c|c|c|c|c|}
\hline \multirow[b]{2}{*}{ Group } & \multirow[b]{2}{*}{ Rabbits ID } & \multirow[b]{2}{*}{ Vaccine } & \multirow[b]{2}{*}{ Technique } & \multicolumn{5}{|c|}{ Humoral Response } \\
\hline & & & & Day 0 & Day 7 & Day 21 & Day 28 & Day 35 \\
\hline \multirow{9}{*}{ R-G3 } & \multirow{3}{*}{$\# 446$} & \multirow{3}{*}{$1 \times$ M-RHD } & iELISA & 0.31 & 0.36 & 2.3 & 3.05 & 4.78 \\
\hline & & & IFT & $<2$ & 3.5 & 6.5 & 8 & 9 \\
\hline & & & SNT & $<1 / 4$ & $<1 / 4$ & $1 / 8$ & $1 / 16$ & $1 / 64$ \\
\hline & \multirow{3}{*}{ \#447 } & \multirow{3}{*}{$1 \times$ M-RHD } & iELISA & 0.35 & 0.21 & 5.32 & 5.42 & 5.39 \\
\hline & & & IFT & $<2$ & 4.5 & 9.5 & 10 & 10 \\
\hline & & & SNT & $<1 / 4$ & $1 / 4$ & $1 / 128$ & $1 / 128$ & $1 / 128$ \\
\hline & \multirow{3}{*}{ \#448 } & \multirow{3}{*}{$1 \times$ M-RHD } & iELISA & 0.26 & 0.51 & 1.21 & 1.09 & 2.15 \\
\hline & & & IFT & $<2$ & 4 & 5.5 & 6 & 7 \\
\hline & & & SNT & $<1 / 4$ & $<1 / 4$ & $1 / 4$ & $1 / 8$ & $1 / 8-1 / 16$ \\
\hline
\end{tabular}

$1 \times$ M-H-vaccinated with $1.95 \times 10^{4} \mathrm{ffu}$ dose of Mixohipra-H; $1 \times-\mathrm{M}-\mathrm{RHD}$-vaccinated with 1 dose of Myxo RHD-PLUS; Not vac-not vaccinated.

\subsection{Hematologic and Biochemical Analyses of Blood Samples Obtained during Vaccination}

Monitoring of the different parameters analysed in the hemogram (RBC, HCT, HGB, $\mathrm{MCV}, \mathrm{MCH}, \mathrm{MCHC}$, RDW, reticulocytes, WBC, neutrophils, lymphocytes, monocytes, eosinophils, basophils, platelets, MPV, PDW, PCT) showed no remarkable changes after vaccination in any of the hares and rabbits. Likewise, regarding the biochemistry analyses, no remarkable variations in glucose, creatinine, blood urea nitrogen, ALT, ALKP or GGT values were observed. Interestingly, the albumin/globulins ratio, in the case of hare \#043 and hare \#044 (both from H-G3), showed a decrease between days 21 and 28 after the first vaccination, coinciding with the seroconversion.

By day 30 after the challenge, sick hares showed lower haematocrit of $35.33 \pm 4.51 \%$ (compared to $53.44 \pm 3.24 \%$ in the healthy animals) and a leucocytosis of $18.82 \pm 4.86 \mathrm{~K} / \mu \mathrm{L}$ (WBC) (compared to $5.65 \pm 1.54 \mathrm{~K} / \mu \mathrm{L}$ (WBC) in the healthy hares), mainly resulting from a neutrophilia of $15.30 \pm 7.32 \mathrm{~K} / \mu \mathrm{L}$ (compared to $2.53 \pm 1.33 \mathrm{~K} / \mu \mathrm{L}$ in the healthy hares).

\subsection{Clinical Course after Challenge}

Hares \#233 (H-G1) and \#042 (H-G3) did not develop any signs of disease (Table 3) after the first virus inoculation of $1 \mathrm{~mL}$ (100 ffu $/ \mathrm{mL}$, subcutaneously), and no virus was detected in the blood, stool or conjunctival swab on day 15. Additionally, these hares did not seroconvert and were inoculated a second time, 30 days after the first virus challenge, with the same isolate, but a 10-fold higher dose $(1 \mathrm{~mL}$ of $1000 \mathrm{ffu} / \mathrm{mL})$. Both died after developing signs of myxomatosis (Table 3 ).

The average incubation period of myxomatosis in hares was $11.3 \pm 2.6$ days considering the 8 hares, and $11.8 \pm 2.2$ excluding the two seropositive hares (\#043 and \#044), taking as a clinical reference the alterations developed in the eyelids (Table 3 and Figure 3). The evolution of oedema in the genitals was not monitored, given the difficulty of handling the sick animals and the stress effect of such handling. From the onset of symptoms, it took an average of $17.8 \pm 8.5$ days until death occurred or euthanasia was carried out for animal welfare purposes. Hares \#043 and \#044 recovered totally, respectively, in 13 and 19 days after the challenge. Hares of study 3 were not submitted to challenge. 

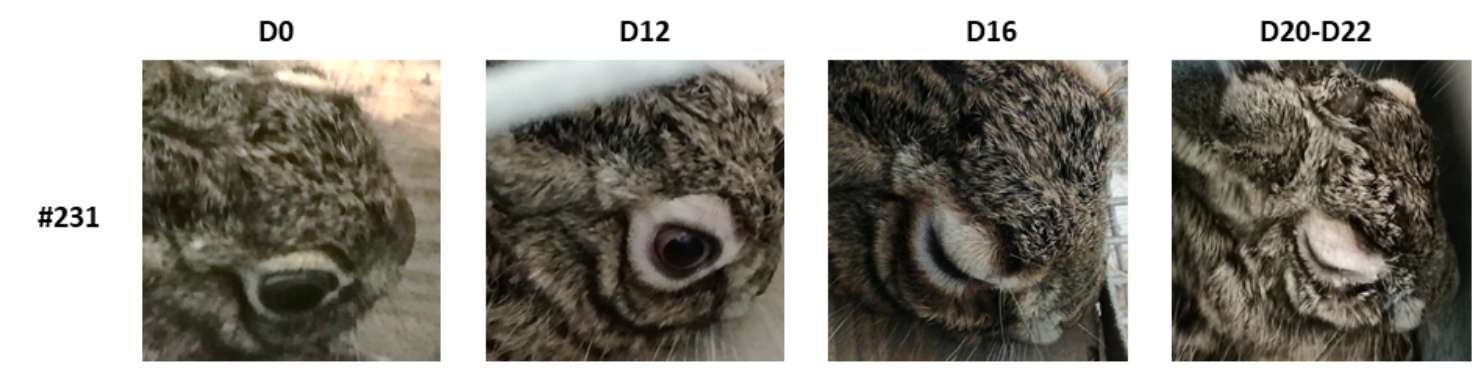

$\# 232$
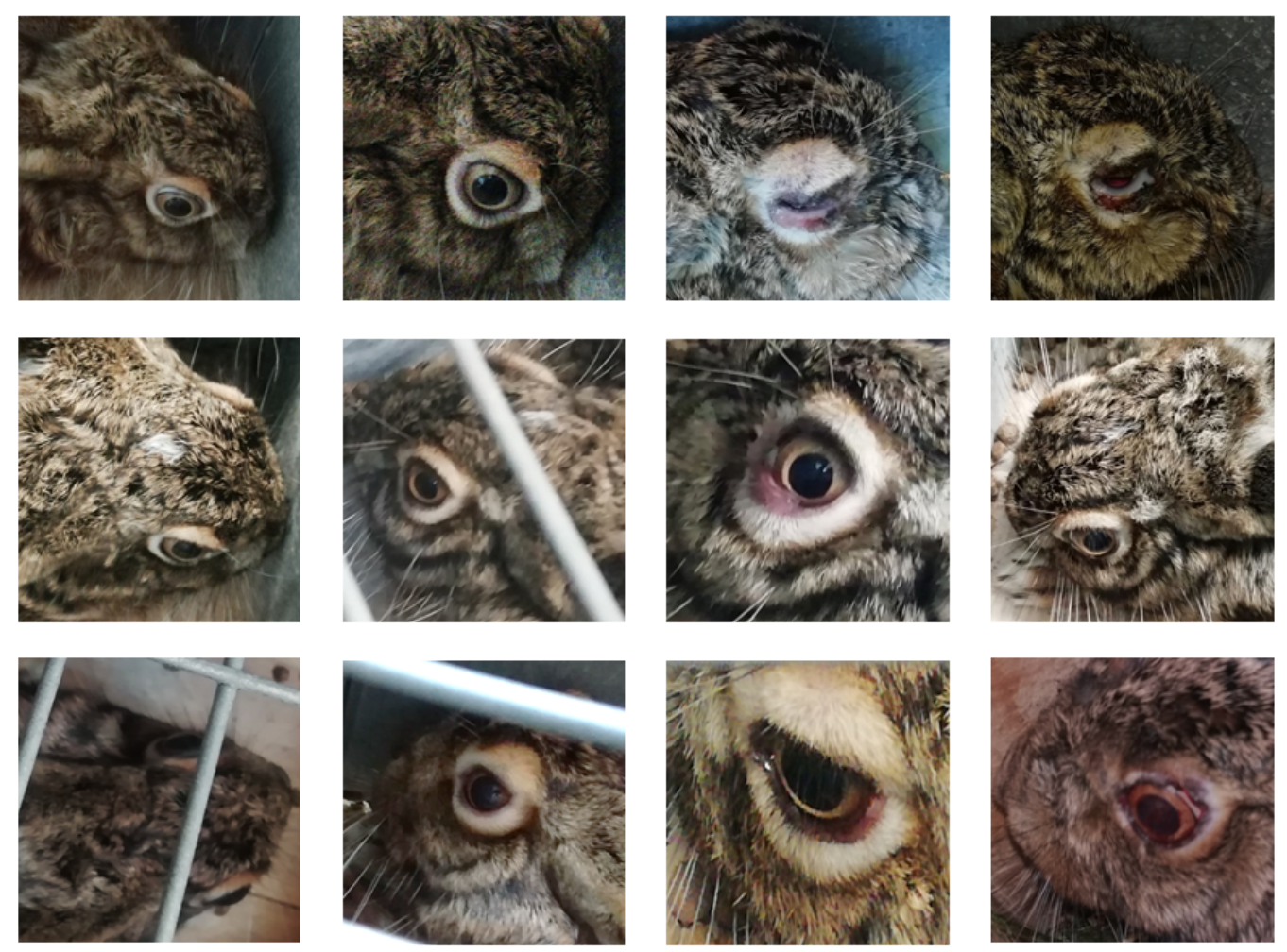

Figure 3. Clinical signs of myxomatosis of four hares involved in the study. Hares \#231 and \#232 (H-G1) were not vaccinated. Hares \#043 and \#044 belonged to the H-G3 group (vaccinated with $2.90 \times 10^{5} \mathrm{ffu}$ dose of Mixohipra-FSA). D-day after challenge.

Hares \#233 (from H-G1, not vaccinated), \#078 (from H-G2, vaccinated with low dose of Mixohipra-FSA and Mixohipra-H) and \#042 (from H-G3, vaccinated with a high dose of Mixohipra-FSA and Mixohipra-H but challenged twice) developed severe myxomatosis and died. These hares, like those euthanized after developing severe myxomatosis (hares \#231 and \#232 not vaccinated (H-G1) and hare \#076 vaccinated with low dose (H-G2)) lost on average $483.3 \pm 147.2 \mathrm{~g}$ of weight from the day of virus challenge to the day of death (Table 3). In contrast, hares that developed light and shorter forms of the disease (hares \#043 and \#044 vaccinated with high dose (H-G3)) lost at the most $116.7 \pm 28.9 \mathrm{~g}$ (Table 3). Comparing the hares that became very sick ( $>50 \%$ eyelid closed) with healthy ones, food intake decreased from 170-200 g of oats per day to $40-50 \%$ less at maximum. The opposite happened with water intake that rose from $50-70 \mathrm{~mL}$ to $80-110 \mathrm{~mL}$ per day at maximum.

The average incubation period of myxomatosis in positive control rabbits (R-G1, not vaccinated) was 8 days for the rabbits (\#449 and \#451) inoculated with isolate 20545PT20 (isolated from a wild rabbit) and 8 days for the rabbits \#000 and \#001 inoculated with isolate 38455PT18 (isolated from an Iberian hare) considering the alterations in the eyelids (oedema and eye closure) as reference (Table 4 and Figure 4 ), corresponding to an average of $6.3 \pm 2.1$ days in the four rabbits. 
D4

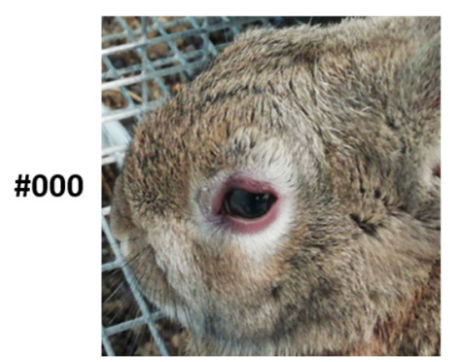

D8

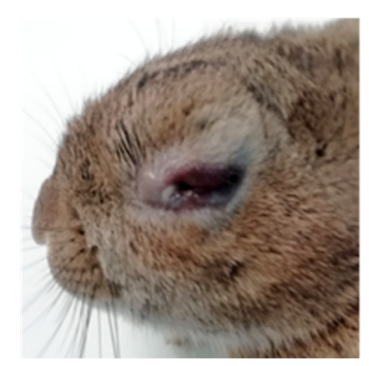

D11

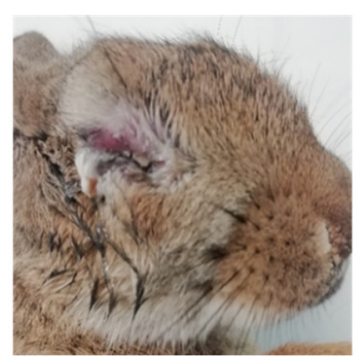

Figure 4. The clinical course of rabbit \#000 (non-vaccinated, belonging to group R-G1) inoculated with virus isolated from Iberian hare $(1 \mathrm{~mL}$ of $1000 \mathrm{ffu} / \mathrm{mL}, 38455 \mathrm{PT} 18)$. D-day after challenge. Note very mild (D4), moderate (D8) and (D11) marked eyelid oedema.

In rabbits, it took an average of $5.25 \pm 1.5$ days from the onset of symptoms until death occurred, and an average of $11.5 \pm 0.56$ days from the virus challenge until death, with an average weight loss of $73.5 \pm 45.0 \mathrm{~g}$. None of the vaccinated rabbits showed symptoms of myxomatosis (Table 4).

Interestingly, the incubation period among rabbits inoculated with wild rabbit virus isolate (20545PT20) was longer (8 days) compared to Iberian hare virus isolate (38455PT20) (4.5 days). After the onset of symptoms, rabbits inoculated with strain 20545PT20 died within 4 days and rabbits inoculated with a strain of Iberian hare died within 6.5 days. As expected, rabbits with a longer course of disease showed more severe pathological signs (Table 4).

The MYXV antibodies estimated by iELISA at the death or recovery moments revealed RI10 values of 9.12, 1.82 and 0.23 for the \#231, \#232, \#233 (H-G1, nonvaccinated); 2.62 and 0.12 for \#076, \#078 (H-G2, vaccinated with the lower dose); and 0.23, 31.00 and 28.90 for \#042, \#043 and \#044 (H-G3, vaccinated with the higher dose), respectively.

Hare \#010 (H-G4) did not show seroconversion after the first challenge with $100 \mathrm{ffu}$, but had a small increase in RI10 after the second inoculation to 13.32. LeHV-5 was neither detected in blood cells nor skin samples, suggesting the absence of latency or active replication in any of the hares, ruling out the LeHV-5 contribution to the clinical picture and immune response.

In the rabbits, he MYXV antibodies estimated by iELISA at the death (for R-G1) or fifteen days after challenge (R-G2 and R-G3) revealed RI10 lower than 2.0 for the \#449, $\# 451, \# 000$ and \#001 (R-G1, nonvaccinated); 21.79, 4.31 and 5.71 for \#442,\#444, and \#445 (R-G2, vaccinated with Mixohipra-H); and 33.02, 23.44, 24.48 for \#446, \#447 and \#448 (R-G3, vaccinated with Myxo-RHD PLUS), respectively.

\subsection{Virus Presence in Drinking Water and Faeces}

During the two vaccination trials, no MYXV-DNA was detectable in the drinking water or the hares' faeces prior challenge.

MYXV-DNA was detected in faeces of hare \#231 (H-G1), seven days after virus challenge, four days before the first signs of disease were noticed. For the remaining hares, virus shedding coincided with the appearance of the first clinical signs or appeared 3 to 4 days later, around day 15 or 16 after the virus challenge. The maximum viral load found on faeces was $1.10 \times 10^{9} \mathrm{DNA}$ copies/mg and the average value was $4.00 \times 10^{7}$ DNA copies /mg, considering only the DNA-positive samples. The virus was no longer detected in faeces after the animals recovered clinically (clinical signs disappeared) or, in some cases, $48 \mathrm{~h}$ before the disappearance of signs of disease. 
Table 3. Clinical data of Iberian hares after challenge with ha-MYXV (38455PT18).

\begin{tabular}{|c|c|c|c|c|c|c|c|c|c|}
\hline \multirow[b]{2}{*}{ Group } & \multirow[b]{2}{*}{ Animal ID } & \multirow[b]{2}{*}{0} & \multicolumn{7}{|c|}{ Days after Virus Challenge } \\
\hline & & & $1-9$ & 10-15 & $16-20$ & $21-25$ & $26-30$ & $31-40$ & D41-D50 \\
\hline \multirow{3}{*}{ H-G1 } & $\begin{array}{c}\text { Hare } \\
\text { \#231 } \\
\text { Not vac }\end{array}$ & \multirow{5}{*}{$\begin{array}{l}\text { Virus challenge } \\
\text { with } 1 \mathrm{~mL} \\
(100 \mathrm{ffu} / \mathrm{mL}) \text { of } \\
\text { ha-MYXV } \\
\text { (38455PT18) }\end{array}$} & $\mathrm{N}$ & $\begin{array}{c}\text { D11-very mild eyelid } \\
\text { oedema. } \\
<25 \% \text { of eye closure. } \\
\text { D13—-mild eyelid } \\
\text { oedema. }<25 \% \text { of eye } \\
\text { closure. } \\
\text { D14-moderate eyelid } \\
\text { oedema. } \\
50 \% \text { of eye closure. }\end{array}$ & $\begin{array}{l}\text { D16 marked } \\
\text { eyelid oedema. } \\
\text { 50-75\% of eye } \\
\text { closure. }\end{array}$ & $\begin{array}{l}\text { D25 marked } \\
\text { eyelid oedema. } \\
>75 \% \text { of eye } \\
\text { closure. }\end{array}$ & $\begin{array}{l}\text { D30-marked } \\
\text { eyelid and } \\
\text { anogenital } \\
\text { oedema. } 100 \% \text { of } \\
\text { eye closure. } \\
\text { Anorexia and } \\
\text { dyspnea. } \\
\text { Euthanasia. }\end{array}$ & & \\
\hline & $\begin{array}{c}\text { Hare } \\
\text { \#232 } \\
\text { Not vac }\end{array}$ & & $\mathrm{N}$ & $\begin{array}{c}\text { D12- mild eyelid } \\
\text { oedema. }<25 \% \text { of eye } \\
\text { closure. } \\
\text { D14-moderate eyelid } \\
\text { oedema. } \\
25-50 \% \text { of eye closure. }\end{array}$ & $\begin{array}{l}\text { D18 marked } \\
\text { eyelid oedema. } \\
\text { 50-75\% of eye } \\
\text { closure. }\end{array}$ & $\begin{array}{l}\text { D25 marked } \\
\text { eyelid oedema. } \\
>75 \% \text { of eye } \\
\text { closure. }\end{array}$ & $\begin{array}{c}\text { D30 marked } \\
\text { eyelid and } \\
\text { anogenital } \\
\text { oedema. } 100 \% \text { of } \\
\text { eye closure. } \\
\text { Anorexia and } \\
\text { dyspnea. } \\
\text { Euthanasia. }\end{array}$ & & \\
\hline & $\begin{array}{c}\text { Hare } \\
\text { \#233 } \\
\text { Not vac }\end{array}$ & & $\mathrm{N}$ & $\mathrm{N}$ & $\mathrm{N}$ & $\mathrm{N}$ & $\begin{array}{c}\text { D30-Second } \\
\text { virus challenge } \\
\text { with } 1000 \mathrm{ffu} \text { of } \\
\text { ha-MXYV } \\
\text { (38455PT18), day } \\
102 \text { in Figure } 1 .\end{array}$ & $\begin{array}{l}\text { D40-very mild } \\
\text { eyelid oedema. } \\
<25 \% \text { of eye } \\
\text { closure. } \\
\text { D42-mild eyelid } \\
\text { oedema. } \\
<25 \% \text { of eye } \\
\text { closure. }\end{array}$ & $\begin{array}{l}\text { D45-Marked } \\
\text { eyelid, foreskin } \\
\text { and anogenital } \\
\text { oedema. 50-75\% } \\
\text { of eye closure. } \\
\text { Anorexia. } \\
\text { D50-Death }\end{array}$ \\
\hline \multirow[t]{2}{*}{ H-G2 } & $\begin{array}{c}\text { Hare } \\
\text { \#076 } \\
1 \times \mathrm{M}-\mathrm{FSA} \\
1 \times \mathrm{M}-\mathrm{H}\end{array}$ & & $\mathrm{N}$ & & $\begin{array}{l}\text { D16-very mild } \\
\text { eyelid oedema. } \\
<25 \% \text { of eye } \\
\text { closure. } \\
\text { D18-very mild } \\
\text { eyelid oedema. } \\
<25 \% \text { of eye } \\
\text { closure. }\end{array}$ & $\begin{array}{l}\text { D20-mild eyelid } \\
\text { oedema. } \\
<25 \% \text { of eye } \\
\text { closure. }\end{array}$ & $\begin{array}{c}\text { D20-moderate } \\
\text { eyelid oedema. } \\
25-50 \% \text { of eye } \\
\text { closure. } \\
\text { D30-marked } \\
\text { eyelid oedema. } \\
50-75 \% \text { of eye } \\
\text { closure. }\end{array}$ & $\begin{array}{l}\text { D40-marked } \\
\text { eyelid oedema. } \\
>75 \% \text { of eye } \\
\text { closure. }\end{array}$ & $\begin{array}{l}\mathrm{D} 48-\text { marked } \\
\text { eyelid and } \\
\text { foreskin oedema. } \\
>75 \% \text { of eye } \\
\text { closure. } \\
\text { Anorexia and } \\
\text { dyspnoea. } \\
\text { Euthanasia. }\end{array}$ \\
\hline & $\begin{array}{c}\# 078 \\
\text { Hare } \\
1 \times \text { M-FSA } \\
1 \times \mathrm{M}-\mathrm{H}\end{array}$ & & $\mathrm{N}$ & $\begin{array}{l}\text { D12-very mild eyelid } \\
\text { oedema. } \\
<25 \% \text { of eye closure. }\end{array}$ & $\begin{array}{l}\text { D16 - mild eyelid } \\
\text { oedema. } \\
<25 \% \text { of eye } \\
\text { closure. }\end{array}$ & $\begin{array}{l}\text { D20-mild eyelid } \\
\text { oedema. } \\
<25 \% \text { of eye } \\
\text { closure. Death }\end{array}$ & & & \\
\hline
\end{tabular}


Table 3. Cont.

\begin{tabular}{|c|c|c|c|c|c|c|c|c|c|}
\hline \multirow[b]{2}{*}{ Group } & \multirow[b]{2}{*}{ Animal ID } & \multirow[b]{2}{*}{0} & \multicolumn{7}{|c|}{ Days after Virus Challenge } \\
\hline & & & $1-9$ & $10-15$ & $16-20$ & $21-25$ & $26-30$ & $31-40$ & D41-D50 \\
\hline \multirow{3}{*}{ H-G3 } & $\begin{array}{c}\text { Hare } \\
\# 042 \\
10 \times \mathrm{M}-\mathrm{FSA} \\
10 \times \mathrm{M}-\mathrm{H}\end{array}$ & & $\mathrm{N}$ & $\mathrm{N}$ & $\mathrm{N}$ & $\mathrm{N}$ & $\begin{array}{c}\text { D30-Second } \\
\text { virus challenge } \\
\text { with } 1000 \mathrm{ffu} \text { of } \\
\text { ha-MXYV } \\
\text { (38455PT18), day } \\
102 \text { in Figure } 1 .\end{array}$ & $\begin{array}{l}\text { D40-very mild } \\
\text { eyelid oedema. } \\
<25 \% \text { of eye } \\
\text { closure. } \\
\text { D45-mild eyelid } \\
\text { oedema. } \\
<25 \% \text { of eye } \\
\text { closure. }\end{array}$ & $\begin{array}{c}\text { D50-mild eyelid } \\
\text { oedema. } \\
<25 \% \text { of eye } \\
\text { closure } \\
\text { D } 60-\text { moderate } \\
\text { eyelid, testis and } \\
\text { foreskin oedema. } \\
25-50 \% \text { of eye } \\
\text { closure. Anorexia. } \\
\text { Death. }\end{array}$ \\
\hline & $\begin{array}{c}\text { Hare } \\
\# 043 \\
10 \times \mathrm{M}-\mathrm{FSA} \\
10 \times \mathrm{M}-\mathrm{H}\end{array}$ & & $\mathrm{N}$ & $\begin{array}{c}\text { D12-very mild eyelid } \\
\text { oedema. }<25 \% \text { of eye } \\
\text { closure. }\end{array}$ & $\begin{array}{l}\text { D16-Left } 1 \\
\text { ower eyelid } \\
\text { erythema. }\end{array}$ & D25-N & $\mathrm{N}$ & $\mathrm{N}$ & $\mathrm{N}$ \\
\hline & $\begin{array}{c}\text { Hare } \\
\text { \#044 } \\
10 \times \text { M-FSA } \\
10 \times \mathrm{M}-\mathrm{H}\end{array}$ & & $\begin{array}{l}\text { D7-mild eyelid } \\
\text { oedema. } \\
<25 \% \text { of eye } \\
\text { closure. }\end{array}$ & $\begin{array}{c}\text { D12-mild eyelid } \\
\text { oedema. }<25 \% \text { of eye } \\
\text { closure. }\end{array}$ & $\begin{array}{c}\text { D14-D20- } \\
\text { moderate eyelid } \\
\text { oedema. } \\
\text { 25-50\% of eye } \\
\text { closure. }\end{array}$ & $\begin{array}{l}\text { D21-Beginning } \\
\text { of crusting and } \\
\text { improvement of } \\
\text { eye opening. }\end{array}$ & $\begin{array}{l}\mathrm{D} 26-\mathrm{N} \text {, in } \\
\text { addition to scars } \\
\text { on the eyelids. }\end{array}$ & & \\
\hline H-G4 & $\begin{array}{c}\text { Hare } \\
\# 10 \\
\text { Natural immunity }\end{array}$ & & $\mathrm{N}$ & $\mathrm{N}$ & $\mathrm{N}$ & $\mathrm{N}$ & $\begin{array}{l}\text { D30-Second virus } \\
\text { challenge with } \\
1000 \mathrm{ffu} \text { of } \\
38455 \mathrm{PT} 18 .\end{array}$ & $\mathrm{N}$ & $\mathrm{N}$ \\
\hline
\end{tabular}

$1 \times$ M-FSA,-vaccinated with $2.90 \times 10^{4}$ ffu dose of Mixohipra-FSA; $10 \times$ M-FSA-vaccinated with $2.90 \times 10^{5}$ ffu dose of Mixohipra-FSA; $1 \times$ M-H—vaccinated with $1.95 \times 10^{4}$ ffu dose of Mixohipra-H; $10 \times \mathrm{M}-\mathrm{H}$-vaccinated with $1.95 \times 10^{5}$ ffu dose of Mixohipra-H, Not vac-Not vaccinated; D-day, N—no disease signs. 
Table 4. Clinical data of wild rabbits after challenge with ha-MYXV isolated from wild rabbit (20545PT20) or Iberian hare (38455PT18).

\begin{tabular}{|c|c|c|c|c|c|c|c|c|c|}
\hline \multirow[b]{2}{*}{ Group } & \multirow[b]{2}{*}{ Animal ID } & \multirow[b]{2}{*}{0} & \multicolumn{7}{|c|}{ Days after Virus Challenge } \\
\hline & & & $1-9$ & 10-15 & $16-20$ & $21-25$ & $26-30$ & $31-40$ & D41-D50 \\
\hline \multirow{4}{*}{$\begin{array}{c}\text { RG-1 } \\
\text { Not vac }\end{array}$} & $\begin{array}{c}\text { Rabbit } \\
\# 000\end{array}$ & \multirow{2}{*}{$\begin{array}{c}\text { Virus challenge of } \\
1000 \mathrm{ffu} \text { of ha-MYXV } \\
\text { (38455PT18), day } 65 \\
\text { in Figure } 1 .\end{array}$} & $\begin{array}{c}\text { D4-very mild eyelid oedema. } \\
\text { No genital changes. } \\
\text { D8-moderate eyelid and } \\
\text { genital oedema. } 50-75 \% \text { of eye } \\
\text { closure. }\end{array}$ & $\begin{array}{l}\text { D11-Marked eyelid, } \\
\text { foreskin and genital } \\
\text { oedema. }>75 \% \text { of eye } \\
\text { closure Anorexia. Death. }\end{array}$ & & & & & \\
\hline & $\begin{array}{c}\text { Rabbit } \\
\# 001\end{array}$ & & $\begin{array}{c}\text { D5—-very mild eyelid and } \\
\text { genital oedema. } \\
\text { D8-moderate eyelid and } \\
\text { genital oedema. } 50-75 \% \text { of eye } \\
\text { closure. }\end{array}$ & $\begin{array}{l}\text { D11-Marked eyelid, } \\
\text { foreskin and genital } \\
\text { oedema. }>75 \% \text { of eye } \\
\text { closure Anorexia. Death. }\end{array}$ & & & & & \\
\hline & $\begin{array}{c}\text { Rabbit } \\
\# 449\end{array}$ & \multirow{8}{*}{$\begin{array}{c}\text { Virus challenge of } \\
1000 \mathrm{ffu} \text { of ha-MYXV } \\
\text { (20545PT20), day } 35 \\
\text { in Figure } 1 .\end{array}$} & $\begin{array}{l}\text { D8-very mild eyelid oedema. } \\
<25 \% \text { of eye closure. No genital } \\
\text { changes. }\end{array}$ & $\begin{array}{l}\text { D12-Very mild eyelid } \\
\text { and foreskin oedema. } \\
<25 \% \text { of eye closure. No } \\
\text { genital oedema. Death. }\end{array}$ & & & & & \\
\hline & $\begin{array}{c}\text { Rabbit } \\
\# 451\end{array}$ & & $\begin{array}{l}\text { D8-very mild eyelid oedema. } \\
<25 \% \text { of eye closure. No genital } \\
\text { changes. }\end{array}$ & $\begin{array}{l}\text { D12-Very mild eyelid } \\
\text { and foreskin oedema. } \\
<25 \% \text { of eye closure. No } \\
\text { genital oedema Death. }\end{array}$ & & & & & \\
\hline \multirow{3}{*}{$\begin{array}{c}\mathrm{RG}-2 \\
1 \times \mathrm{M}-\mathrm{H}\end{array}$} & $\begin{array}{c}\text { Rabbit } \\
\# 442\end{array}$ & & $\mathrm{~N}$ & $\mathrm{~N}$ & $\mathrm{~N}$ & $\mathrm{~N}$ & $\mathrm{~N}$ & $\mathrm{~N}$ & $\mathrm{~N}$ \\
\hline & $\begin{array}{c}\text { Rabbit } \\
\# 444\end{array}$ & & $\mathrm{~N}$ & $\mathrm{~N}$ & $\mathrm{~N}$ & $\mathrm{~N}$ & $\mathrm{~N}$ & $\mathrm{~N}$ & $\mathrm{~N}$ \\
\hline & $\begin{array}{c}\text { Rabbit } \\
\# 445\end{array}$ & & $\mathrm{~N}$ & $\mathrm{~N}$ & $\mathrm{~N}$ & $\mathrm{~N}$ & $\mathrm{~N}$ & $\mathrm{~N}$ & $\mathrm{~N}$ \\
\hline \multirow{3}{*}{$\begin{array}{c}\text { RG-3 } \\
1 \times \text { M-RHD }\end{array}$} & $\begin{array}{c}\text { Rabbit } \\
\# 446\end{array}$ & & $\mathrm{~N}$ & $\mathrm{~N}$ & $\mathrm{~N}$ & $\mathrm{~N}$ & $\mathrm{~N}$ & $\mathrm{~N}$ & $\mathrm{~N}$ \\
\hline & $\begin{array}{c}\text { Rabbit } \\
\# 447\end{array}$ & & $\mathrm{~N}$ & $\mathrm{~N}$ & $\mathrm{~N}$ & $\mathrm{~N}$ & $\mathrm{~N}$ & $\mathrm{~N}$ & $\mathrm{~N}$ \\
\hline & $\begin{array}{c}\text { Rabbit } \\
\# 448\end{array}$ & & $\mathrm{~N}$ & $\mathrm{~N}$ & $\mathrm{~N}$ & $\mathrm{~N}$ & $\mathrm{~N}$ & $\mathrm{~N}$ & $\mathrm{~N}$ \\
\hline
\end{tabular}

1× M-H—vaccinated with $1.95 \times 10^{4}$ ffu dose of Mixohipra-H; 1× M-RHD—vaccinated with 1 dose of Myxo-RHD PLUS; Not vac-not vaccinated; D-day, N—no disease signs. 
The type of drinking fountain used for hares consisted of a small shell-shaped reservoir containing a limited volume of water (about $5 \mathrm{~mL}$ ), from which water was sampled. In hares that developed erosive lesions in the oral mucosa (\#231,\#232, \#233, \#042 and \#076) the virus was detected in water samples by qPCR. The average viral load in the DNA-positive drinking water samples was $5.00 \times 10^{6} \mathrm{DNA}$ copies $/ \mathrm{mL}$ with a minimum of $6.32 \times 10^{3}$ and a maximum of $4.73 \times 10^{7} \mathrm{DNA}$ copies/mL. For one drinking water sample (with a viral load of $1.30 \times 10^{7}$ ), it was possible to isolate the virus in RK13 cells.

The faeces analyses were not performed in the rabbit trial due to the characteristics of the cages that do not allow the separation of the faeces from each animal. Likewise, the rabbits' pacifier drinkers do not allow the analysis of the drinking water, and therefore this analysis was not performed.

\subsection{Necropsy, Histopathology and Virus Loads in Tissues}

The necropsy and histopathology data of hares from group H-G1 (\#231, \#232, \#233), H-G2 (\#076 and \#078) and H-G3 (\#042) revealed the expected lesions found in naturally infected animals by ha-MYXV $[3,19,20]$ namely the oedema of eyelids and ano-genital, the production of myxoid tissue and the secondary bacterial infection. No remarkable histopathological changes were observed in animals \#043 and \#044 (H-G3) artificially immunized by the high dose vaccine, or in \#10 (H-G4) naturally immunized.

Rabbits \#449,\#451,\#000, \#001 (Table 5) revealed the expected lesions found in naturally infected rabbits by the ha-MYXV $[7,8]$, namely eyelid, ano-genital and alveolar oedemas.

Organs sampled but without description in Table 5 were considered without relevant changes. No myxoma lesions (also called "pseudotumours" or "tumour-like lesions") were observed in the skin of any animal (rabbit and hares) during the clinical course of the disease or after death, not even in the virus inoculation zone.

No pathological findings in necropsy and histopathology were found in hares \#043 (H-G3, vaccinated with high dose) and \#010 (H-G4, naturally immunized) and all the vaccinated rabbits: \#442, \#444 and \#445 (R-G2, vaccinated with M-H) and \#446, \#447 and \#448 (R-G3, vaccinated with Myxo-RHD PLUS), and they were also negative to bacteriological and parasitological analyses (not included in Table 5). Hare \#044 (H-G3) only presented mild scar on the eyelids.

Several pathogenic bacteria were found in the animals included in this study (Table 5). In general, mild infections by Eimeria species were found in sick animals, and these parasites were very frequently also found in wild animals that died from myxomatosis or in healthy animals [20]. Despite the infection, no signs compatible with enteritis were detected at necropsy and no diarrhoea events were registered during the entire course of the trial in these animals.

The viral loads in the different tissues (Table 6) were determined by qPCR [16]. The highest viral loads were registered in the eyelids (mean of all positive hares of $1.10 \times 10^{10} \pm 1.02 \times 10^{10}$ DNA copies/mg tissue and mean of all positive rabbits of $4.79 \times 10^{10} \mathrm{DNA}$ copies $/ \mathrm{mg}$ tissue), lips (mean of all positive hares of $9.30 \times 10^{9} \pm 1.60 \times 10^{10}$ DNA copies/mg tissue and mean of all positive rabbits of $1.22 \times 10^{9} \pm 8.88 \times 10^{8} \mathrm{DNA}$ copies $/ \mathrm{mg}$ tissue) and genitalia (mean of all positive hares of $1.65 \times 10^{10} \pm 2.52 \times 10^{10}$ DNA copies/mg tissue and mean of all positive rabbits of $2.53 \times 10^{10} \pm 2.43 \times 10^{10} \mathrm{DNA}$ copies $/ \mathrm{mg}$ tissue).

Overall, no virus was detected in vaccinated rabbits independently of the vaccine used, but was detected in all non-vaccinated rabbits. In all hares submitted to virus challenge, virus was detected in the tissues except for 2 out of the three hares vaccinated with $10 \times$ M-FSA vaccine, which seroconverted. 
Table 5. Necropsy, bacteriological and parasitological data from hares and rabbits

\begin{tabular}{|c|c|c|c|c|c|c|c|c|c|}
\hline \multirow[t]{2}{*}{ Group } & \multirow[t]{2}{*}{$\underset{\text { ID }}{\text { Animal }}$} & \multirow[t]{2}{*}{ Challenge } & \multicolumn{5}{|c|}{ Pathological Examination } & \multirow{2}{*}{$\begin{array}{c}\text { Bacteriological } \\
\text { Examination } \\
\text { from Liver, } \\
\text { Spleen and } \\
\text { Lungs }\end{array}$} & \multirow[t]{2}{*}{$\begin{array}{c}\text { Parasitologica } \\
\text { Examination }\end{array}$} \\
\hline & & & Eyelid/Ano-Genitalia/Lip & Liver & Spleen & Lungs & Kidney/Other & & \\
\hline \multirow[t]{2}{*}{ H-G1 } & $\begin{array}{l}\text { Hare } \\
\# 231\end{array}$ & $\begin{array}{c}100 \mathrm{ffu} \text { of } \\
\text { ha-MYXV isolated } \\
\text { from hare } \\
(38455 \mathrm{PT} 18)\end{array}$ & $\begin{array}{l}\text { Macroscopic: Marked eyelid, lips, } \\
\text { genitalia and anus oedema. Thickening } \\
\text { and congestion of the scrotal sac wall } \\
\text { with necrosis. Accumulation of fibrin } \\
\text { within the scrotal pouches. Congestion of } \\
\text { the testicles. } \\
\text { Microscopic: Eyelid with necrosis of the } \\
\text { epidermis and conjunctiva with bacterial } \\
\text { infiltration. Scrotum with oedema at the } \\
\text { dermo-epidermal junction with } \\
\text { detachment of the epidermis. Lip with } \\
\text { necropurulent dermatitis and presence of } \\
\text { extensive bacterial clusters. Testis with } \\
\text { absence of germ cells, persisting only } \\
\text { Sertoli cells. Epididymis with necrosis of } \\
\text { the lining epithelium and accumulation } \\
\text { of necrotic cells in the lumen of the ducts. } \\
\text { Vas deferens with accumulation of myxoid } \\
\text { tissue underlying the lamina propria. }\end{array}$ & $\begin{array}{c}\text { Moderate } \\
\text { periportal } \\
\text { infiltration by } \\
\text { mononuclear cells }\end{array}$ & $\mathrm{N}$ & $\mathrm{N}$ & $\begin{array}{l}\text { Kidney with } \\
\text { perivascular } \\
\text { lymphocytic } \\
\text { infiltration. } \\
\text { Empty stomach. }\end{array}$ & $\begin{array}{c}\text { Escherichia coli and } \\
\text { Stenotrophomonas } \\
\text { maltophilia }\end{array}$ & $\begin{array}{l}\text { Mild infection } \\
\text { by Eimeria spp. }\end{array}$ \\
\hline & $\begin{array}{l}\text { Hare } \\
\# 232\end{array}$ & & $\begin{array}{l}\text { Macroscopic: Marked eyelid, lips, } \\
\text { genitalia and anus oedema. } \\
\text { Microscopic: Eyelid with epidermal } \\
\text { hyperplasia and extensive proliferation of } \\
\text { myxoid tissue in depth to the conjunctiva. } \\
\text { Lips with epidermal hyperplasia, } \\
\text { ballooning degeneration of keratinocytes, } \\
\text { intense production of myxoid tissue, } \\
\text { infiltration of muscle tissue by } \\
\text { mononuclear cells and heterophils. } \\
\text { Prepuce with extensive and severe } \\
\text { necropurulent dermatitis with strong } \\
\text { bacterial infiltration, myxoid tissue in the } \\
\text { dermis, diffuse infiltration by heterophils } \\
\text { in depth, necropurulent foci. }\end{array}$ & $\begin{array}{c}\text { Cellular } \\
\text { infiltration, } \\
\text { namely by } \\
\text { heterophils in the } \\
\text { porta spaces and } \\
\text { occasionally in the } \\
\text { sinusoid } \\
\text { capillaries. }\end{array}$ & $\begin{array}{l}\text { Marked depletion } \\
\text { of lymphocytes. }\end{array}$ & $\begin{array}{l}\text { Multifocal } \\
\text { purulent } \\
\text { alveolitis. }\end{array}$ & $\begin{array}{l}\text { Kidney with } \\
\text { perivascular } \\
\text { infiltration by } \\
\text { mononuclear cells. } \\
\text { Empty stomach. }\end{array}$ & $\begin{array}{l}\text { Stenotrophomonas } \\
\text { maltophilia, } \\
\text { Staphylococcus } \\
\text { equorum and } \\
\text { Staphylococcus } \\
\text { xylosus }\end{array}$ & $\begin{array}{l}\text { Mild infection } \\
\text { by Eimeria spp. }\end{array}$ \\
\hline
\end{tabular}


Table 5. Cont.

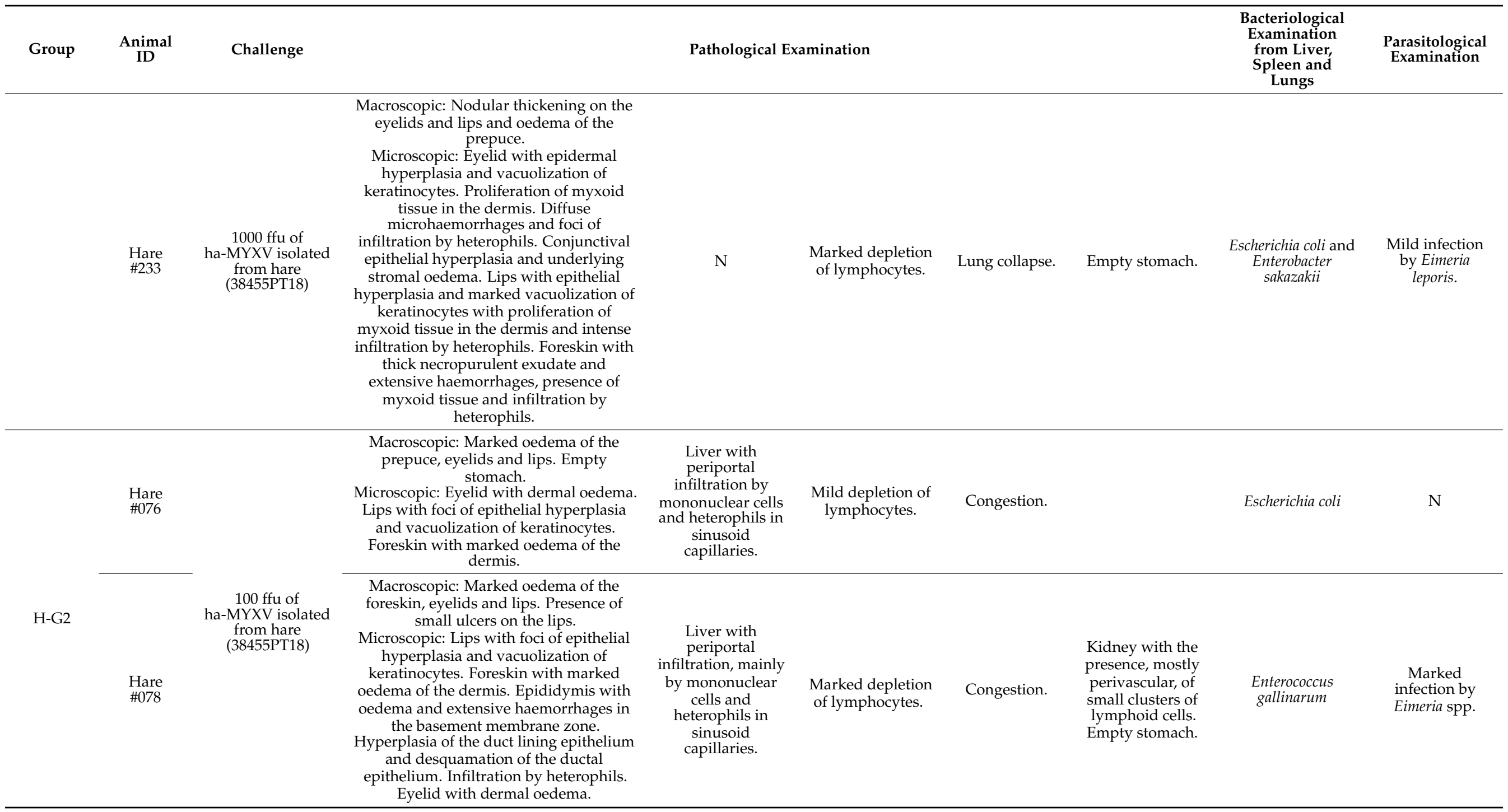


Table 5. Cont.

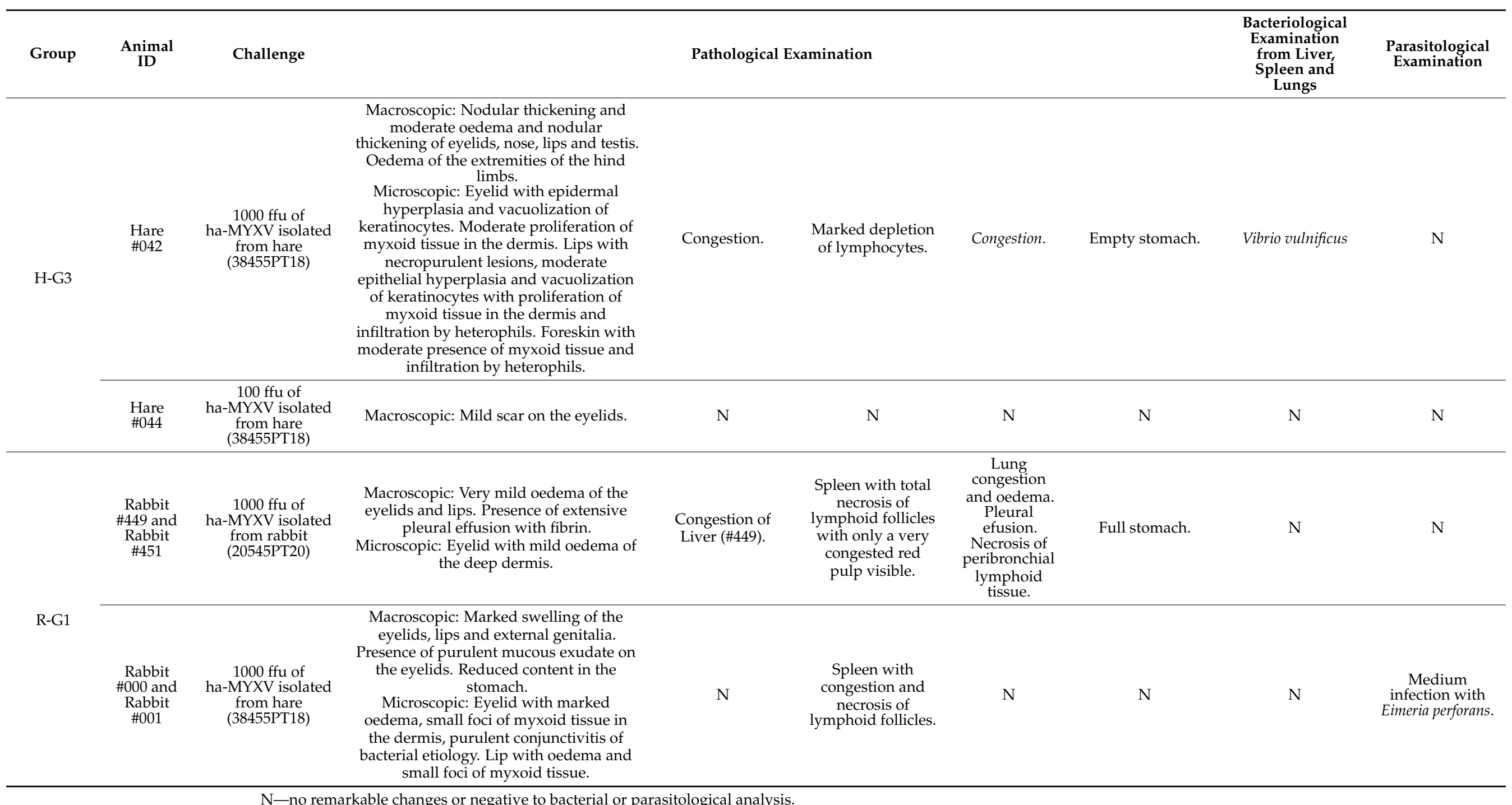


Table 6. Viral loads in the hare and rabbit tissues after challenge.

\begin{tabular}{|c|c|c|c|c|c|c|c|c|c|c|c|c|c|c|c|}
\hline \multirow[b]{2}{*}{ ID } & \multicolumn{2}{|c|}{ Vaccination Data } & \multicolumn{12}{|c|}{ Viral Loads in Different Tissues (DNA Copies/mg Tissue) } & \multirow[b]{2}{*}{$\begin{array}{l}\text { Spinal } \\
\text { Cord }\end{array}$} \\
\hline & 1st & 2nd & $\begin{array}{c}\text { Liver and } \\
\text { Spleen }\end{array}$ & Lung & Duodedum & Kidney & Eyelid & Lip & Genitalia & Urine & $\begin{array}{c}\text { Seminal } \\
\text { Vesicle }\end{array}$ & Faeces & Brain & $\begin{array}{c}\text { Bone } \\
\text { Marrow }\end{array}$ & \\
\hline \multicolumn{16}{|l|}{ Hares } \\
\hline$\# 231$ & Not vac & Not vac & $1.60 \times 10^{7}$ & $1.47 \times 10^{8}$ & $5.76 \times 10^{6}$ & $1.71 \times 10^{7}$ & $2.88 \times 10^{9}$ & $1.75 \times 10^{9}$ & $2.23 \times 10^{7}$ & $7.44 \times 10^{6}$ & $1.78 \times 10^{9}$ & $3.98 \times 10^{8}$ & $4.05 \times 10^{6}$ & $1.31 \times 10^{6}$ & $1.53 \times 10^{6}$ \\
\hline$\# 232$ & Not vac & Not vac & $1.10 \times 10^{8}$ & $1.23 \times 10^{8}$ & $3.66 \times 10^{7}$ & $3.15 \times 10^{9}$ & $1.24 \times 10^{10}$ & $7.47 \times 10^{9}$ & $1.24 \times 10^{10}$ & $5.47 \times 10^{3}$ & $5.42 \times 10^{6}$ & $1.83 \times 10^{6}$ & $4.95 \times 10^{5}$ & $3.70 \times 10^{5}$ & $5.45 \times 10^{6}$ \\
\hline$\# 233$ & Not vac & Not vac & $6.73 \times 10^{8}$ & $6.28 \times 10^{8}$ & $4.03 \times 10^{6}$ & $4.39 \times 10^{8}$ & $1.34 \times 10^{10}$ & $3.88 \times 10^{9}$ & $5.33 \times 10^{10}$ & NT & $5.37 \times 10^{5}$ & $1.52 \times 10^{8}$ & $2.29 \times 10^{8}$ & $6.83 \times 10^{4}$ & $9.91 \times 10^{4}$ \\
\hline$\# 076$ & $1 \times$ M-FSA & $1 \times \mathrm{M}-\mathrm{H}$ & $2.55 \times 10^{5}$ & $2.33 \times 10^{5}$ & $5.59 \times 10^{4}$ & $1.85 \times 10^{6}$ & $1.34 \times 10^{7}$ & $1.11 \times 10^{6}$ & $2.08 \times 10^{8}$ & $2.16 \times 10^{5}$ & ND & $1.16 \times 10^{5}$ & ND & $3.11 \times 10^{3}$ & ND \\
\hline$\# 077$ & $1 \times$ M-FSA & $1 \times \mathrm{M}-\mathrm{H}$ & ND & ND & ND & ND & ND & ND & ND & ND & $\mathrm{ND}$ & ND & ND & ND & ND \\
\hline$\# 078$ & $1 \times \mathrm{M}-\mathrm{FSA}$ & $1 \times \mathrm{M}-\mathrm{H}$ & $1.17 \times 10^{8}$ & $4.39 \times 10^{8}$ & $7.20 \times 10^{7}$ & $2.22 \times 10^{8}$ & $2.89 \times 10^{10}$ & $4.16 \times 10^{10}$ & $5.40 \times 10^{9}$ & NT & $1.36 \times 10^{5}$ & $1.50 \times 10^{9}$ & $6.26 \times 10^{6}$ & $3.22 \times 10^{4}$ & $8.54 \times 10^{6}$ \\
\hline$\# 042$ & $\begin{array}{c}10 \times \\
\text { M-FSA }\end{array}$ & $10 \times \mathrm{M}-\mathrm{H}$ & $2.90 \times 10^{7}$ & $3.06 \times 10^{7}$ & $8.72 \times 10^{6}$ & $1.50 \times 10^{7}$ & $8.46 \times 10^{9}$ & $1.08 \times 10^{9}$ & $7.73 \times 10^{9}$ & NT & NT & $7.51 \times 10^{8}$ & $7.42 \times 10^{4}$ & $9.25 \times 10^{4}$ & $2.36 \times 10^{5}$ \\
\hline$\# 043$ & $\begin{array}{c}10 \times \\
\text { M-FSA }\end{array}$ & $10 \times \mathrm{M}-\mathrm{H}$ & ND & ND & ND & ND & ND & ND & ND & ND & ND & ND & ND & ND & ND \\
\hline$\# 044$ & $\begin{array}{c}10 \times \\
\text { M-FSA }\end{array}$ & $10 \times \mathrm{M}-\mathrm{H}$ & ND & ND & ND & ND & ND & ND & ND & ND & ND & ND & ND & ND & ND \\
\hline$\# 10$ & \multicolumn{2}{|c|}{ Natural immunity } & ND & ND & ND & ND & ND & ND & ND & ND & ND & ND & ND & ND & ND \\
\hline \multicolumn{16}{|c|}{ Rabbits } \\
\hline$\# 442$ & \multicolumn{2}{|c|}{$1 \times \mathrm{M}-\mathrm{H}$} & ND & ND & ND & ND & ND & ND & ND & ND & ND & ND & ND & ND & ND \\
\hline$\# 445$ & & & ND & ND & ND & ND & ND & ND & ND & ND & ND & ND & ND & ND & ND \\
\hline$\# 446$ & \multirow{3}{*}{\multicolumn{2}{|c|}{$1 \times \mathrm{M}$-RHD }} & ND & ND & ND & ND & ND & ND & ND & ND & ND & ND & ND & ND & ND \\
\hline$\# 447$ & & & $\mathrm{ND}$ & ND & ND & ND & ND & ND & ND & ND & ND & ND & ND & ND & ND \\
\hline$\# 448$ & & & ND & ND & ND & ND & ND & ND & ND & ND & ND & ND & ND & ND & ND \\
\hline$\# 449$ & \multicolumn{2}{|c|}{ Not vac } & $2.30 \times 10^{10}$ & $2.03 \times 10^{10}$ & $7.16 \times 10^{8}$ & $9.97 \times 10^{8}$ & $1.29 \times 10^{10}$ & $1.36 \times 10^{9}$ & $4.19 \times 10^{10}$ & $2.84 \times 10^{7}$ & ND & $2.22 \times 10^{4}$ & ND & $1.02 \times 10^{2}$ & ND \\
\hline$\# 451$ & & & $1.24 \times 10^{10}$ & $3.48 \times 10^{10}$ & $1.04 \times 10^{8}$ & $4.94 \times 10^{9}$ & $1.87 \times 10^{10}$ & $9.97 \times 10^{8}$ & $3.01 \times 10^{9}$ & $8.72 \times 10^{6}$ & NT & $1.15 \times 10^{4}$ & ND & $8.91 \times 10^{2}$ & ND \\
\hline$\# 000$ & \multicolumn{2}{|c|}{ Not vac } & $9.91 \times 10^{9}$ & $7.74 \times 10^{10}$ & $1.25 \times 10^{8}$ & $1.45 \times 10^{9}$ & $6.98 \times 10^{10}$ & $2.33 \times 10^{9}$ & $6.07 \times 10^{9}$ & $1.15 \times 10^{8}$ & NT & $1.24 \times 10^{5}$ & $3.13 \times 10^{4}$ & ND & ND \\
\hline$\# 001$ & & & $3.32 \times 10^{8}$ & $2.11 \times 10^{9}$ & $2.93 \times 10^{7}$ & $8.32 \times 10^{9}$ & $9.02 \times 10^{10}$ & $1.89 \times 10^{8}$ & $5.04 \times 10^{10}$ & $2.04 \times 10^{6}$ & NT & $2.25 \times 10^{3}$ & $4.12 \times 10^{3}$ & $2.15 \times 10^{0}$ & ND \\
\hline
\end{tabular}

$1 \times$ M-FSA—vaccinated with $2.90 \times 10^{4} \mathrm{ffu}$ dose of Mixohipra-FSA; $10 \times$ M-FSA—vaccinated with $2.90 \times 10^{5} \mathrm{ffu}$ dose of Mixohipra-FSA; $1 \times$ M-H-vaccinated with $1.95 \times 10^{4} \mathrm{ffu}$ dose of Mixohipra-H; $10 \times \mathrm{M}-\mathrm{H}-$ vaccinated with $1.95 \times 10^{5}$ ffu dose of Mixohipra-, $1 \times-\mathrm{M}$-RHD—vaccinated with 1 dose of Myxo RHD-PLUS; Not vac. Not vaccinated; NT-non tested; ND—non detected H-Iberian hare R-wild rabbit. 


\section{Discussion}

The objectives established for this study were substantially different for the two-animal species. For the Iberian hare, the main objective was to investigate if commercially available MYXV vaccines for use in rabbits might constitute a prophylactic tool for hares until a hare specific vaccine is available. The objectives for the wild rabbit were to prove the efficacy of commercial rabbit vaccines in wild rabbits against the recently emerged ha-MYXV (either isolated from Iberian hare or wild rabbit) and to investigate the susceptibility of wild rabbits to the ha-MYXV isolated from the Iberian hare.

Several vaccines against myxomatosis are currently available and can show protection when used properly in wild rabbits [21]. However, there are some disagreements in determining the effectiveness of vaccination campaigns in the wild as a management measure [22]. Vaccination campaigns of wild rabbits against myxoma virus are usually "blind", and non-systematic: vaccines are often administrated to the animals regardless of their sex, age or serological status [23].

The commercial myxomatosis vaccines contain live attenuated virus because multiplication of the virus, despite being limited, is important for the induction of a robust immune response, comprising also cellular immunity which is key for protection to myxomatosis [24]. As commercial vaccines against myxomatosis contain classic MYXV strains (e.g., VMI 30 strain) or a Shope fibroma virus strain, which are different from ha-MYXV to which the Iberian hare is highly susceptible, low efficacy of commercial rabbit vaccines is expected, given the absence of vaccine virus multiplication in hare cell cultures (personal communication).

The greatest limitation of this study was imposed by the small number of hares and wild rabbits included in the trial (three per group), intended to reduce to a minimum the number of animals, given the current critical situation of these populations and ethical issues. Despite this assumed constraint, our results showed that hares vaccinated with two commercially available vaccines (Mixohipra-FSA and Mixohipra-H) in the conditions recommended for rabbits, did not seroconvert robustly. Nor did the vaccinated hares gain protection against challenge with ha-MYXV, even when a very low dose of challenge virus (100 ffu) was used, close to that used in previous rabbit studies [25,26]. In fact, with this standard vaccination protocol, all vaccinated hares developed severe disease after challenge, similarly to the non-vaccinated controls.

Interestingly, 2 out of the 3 hares vaccinated with a 10-fold higher dose as recommended for domestic rabbits of Mixohipra-FSA, and a 10-fold higher dose of Mixohipra-H 21 days later, induced a satisfactory humoral response against MYXV. However, there was no remarkable change in antibody titres after the Mixohipra-H boost, which seems to indicate that vaccination with Mixohipra-FSA alone might be sufficient to induce protective immunity in hares. It is worth noting that the higher doses were not accompanied by any general or local (inoculation site) reactions. Furthermore, the haematological and biochemical data of the groups of hares vaccinated with the lower doses revealed no differences in globulins, contrasting with the decrease in the albumin/globulin ratio, in the case of hare \#043 and hare \#044 (H-G3), vaccinated with the 10-fold vaccine doses.

This difference in humoral response against these two vaccines, with a higher response against a heterologous vaccine, may be explained, among other reasons, by the fact that Mixohipra-FSA is an adjuvanted (attapulgite) vaccine and Mixohipra-H does not contain adjuvant, according to the manufacturer's documentation. However, further studies are needed to evaluate this hypothesis, namely by testing seroconversion after two successive administrations of Mixohipra- $\mathrm{H}$, without a previously inoculation of Mixohipra-FSA.

The efficient containment of the Iberian hare for clinical evaluation and sampling is extremely difficult and represents a high risk of self-injury (vertebral fracture) due to sudden movements. Therefore, the subcutaneous route was chosen for all administrations considering that intradermal administration implies the total immobilization of the animal for a few minutes to allow the administration of an invariable dose in all animals. 
Interestingly, hares \#042 and \#233 did not produce any disease after the first challenge trial (100 ffu), neither seroconverted after vaccination (\#042) nor virus challenge (\#042 and \#233), showing a potential difference in the genetic susceptibility of some animals. No signs of cervical lymph node reaction were detected after the virus challenge. This can also mean that the subcutaneous route is not the ideal primary site of Myxoma virus multiplication or antigen presentation. Several studies have shown the lower effectiveness of the subcutaneous route in inducing immunity compared with the intradermal route $[27,28]$. The intradermal route allows a longer contact between the antigen and the antigen-presenting cells with a high number of dendritic cells in the derma compared with the subcutaneous tissue [29]. When Myxoma virus is inoculated intradermically, it can enter directly by lymphatic vessels for transport to antigen-presenting cells in the lymph nodes [30]. Considering the specificity of MYXV to epithelial cells, the delivery to the epidermis or dermis may result in superior and quick immune responses when compared to muscle and subcutaneous tissues [28]. This explanation can be also applied to the inoculation of virus during the challenge. Dalton et al. [27] found seropositivity of only $16.6-54 \%$ of rabbits after subcutaneous vaccination with a delay in seroconversion of these animals. However, in these two hares (\#233 and \#042), the second inoculation with $1000 \mathrm{ffu}$ induced the typically fatal disease. This can mean that $100 \mathrm{ffu}$ might be a low dose for a viral challenge by subcutaneous route, and is why a dose of $1000 \mathrm{ffu}$ was used in the challenge carried out on rabbits, bearing in mind that this test was made after that of hares. Studies carried out in rabbits used different viral doses, namely $2 \times 10^{5.4}$ TCID50 (around $1.4 \times 10^{5.4} \mathrm{ffu}$ ) [31], unknown viral load [32] inoculated subcutaneously, or a dose of around $10^{2}$ to $10^{4}$ [33-39] inoculated intradermically.

In wild rabbits, both Mixohipra-H and Nobivac Myxo-RHD PLUS vaccines, administered in the dose recommended for domestic rabbits, induced a humoral response and completely protected the animals from experimental infection, as none of the rabbits' showed signs of disease after challenge. The wild rabbit is the same species as experimental, pet and industrial rabbits so it is expected that a similar response against the vaccination is developed, allowing the vaccine virus infection and replication in this species. According to the previous statement, the humoral and cellular response against the vaccine strain is expected to be protective against the naturally recombinant virus, taking into account that most of (all) the antigenic epitopes of classic MYXV are conserved in this recombinant virus.

Non-vaccinated rabbits succumbed to inoculation with ha-MYXV either isolated from Iberian hare (38455PT18) or wild rabbit (20545PT20), demonstrating, for the first time, the susceptibility of Oryctolagus cuniculus to the recombinant virus directly isolated from Iberian hare. Although these two strains (38455PT18 and 20545PT20) are still being fully characterized, the disruptive insertion of the M009L gene is conserved in both as well as the insertion affecting the M152R gene (Serp-3), a known virulence factor of MYXV [40].

Despite some differences were observed between the animals that developed severe myxomatosis (Tables 3-5), it was not possible to establish any clinical or lesional pattern between the hares of the different groups due to the small size of our sample, as it is likely that the differences found are due to natural inter-individual variability. However, the differences between the anatomopathological patterns found in hares and in rabbits was evident, probably as a result of the more rapid clinical evolution in the latter.

The macroscopic and histopathologic lesions found in hares and rabbits were similar to those described previously $[1,3,7,8,19]$.

Myxomas (tumour-like lesions) were neither found in the skin of the hare or rabbit used in the three studies, nor in wild naturally infected with ha-MYXV [7], although they have already been found in domestic rabbits infected with ha-MYXV [8]. Furthermore, myxomas are not always present in wild hares found dead with ha-MYXV, being only present in around $30 \%$ of hares $[6-8,20]$. According to classic myxoma virus virulence grade classification $[18,41,42]$, mortality of $100 \%$ in seronegative hares would correspond to Grade I viruses. However, in this assay, the average survival time was of $17.8 \pm 8.5$ days after symptoms onset and not $\leq 13$ days as in rabbits infected in Grade I viruses, suggesting 
that this classification is not appropriate for the Iberian hare. More studies are therefore needed to understand these differences.

All the immunized hares and rabbits showed a moderate to high increase of the antibody titres after the challenge, showing a non-sterilizing immunity. Interestingly, rabbit \#10, which acquired immunity by recovering from a natural infection, showed no response after inoculation of $100 \mathrm{ffu}$ of virus, with a small increase in antibodies after the second inoculation.

PCR based viral quantification revealed loads compatible with what was previously described $[3,7,8]$. As expected [7,8,20], a higher viral load was found in the skin (eyelid and lips) and external genitalia, of both hares and rabbits. However, a variable load of virus was found in various organs, proving systemic dissemination. Relatively high virus loads were also found in the central nervous system (brain and spinal cord), as reported previously for the classic virus strains [18].

The viral loads of ha-MYXV found in hares and rabbits were similar, regarding titre and distribution in different organs, suggesting similar pathophysiology and organic distribution of the virus in both species (Table 6), and independent from the dose of virus inoculated (100 or $1000 \mathrm{ffu}$ ). However, since the animals were not euthanized and did not die on the same day, the different periods of viral replication hamper further conclusions.

However, an important difference to highlight is the higher viral load (10-100 × higher titres) in the lungs of rabbits compared to hares, which may be related to the fact that the clinical course in rabbits was more acute. This was true even when comparing the rabbits with the two hares (\#042 and \#233) infected with $1000 \mathrm{ffu}$.

This difference was particularly notable in animals inoculated with wild rabbit strain (\#449 and \#451, inoculated with 20545PT20), whose external lesions were scarcely evident, and that succumbed as a result of pulmonary alterations and accumulation of pleural effusion. These two animals died 12 days after virus inoculation and 4 days after the onset of symptoms. According to classic myxoma virus virulence grade classifications [18,41,42], these two virus strains can be classified as a Grade 1 (the highest virulence).

No particularly important bacteriological pathology was found in hares' histopathology, and opportunistic bacteria were generally found, probably as a result of immunosuppression caused by the myxoma virus [43]. The bacteriological findings were surprising, revealing the presence of several bacteria species in leporids for the first time, namely Stenotrophomonas maltophilia, Enterococcus gallinarum and Vibrio vulnificus, and confirming that secondary bacterial infections may have contributed significantly to the dead of the animals (Table 5). Staphylococcus equorum was also reported in nasal samples from wild rabbits in Azores, Portugal [44], but was never reported in hares, including the Iberian hare. Stenotrophomonas maltophilia was never reported in rabbits or hares, being an aerobic, nonfermentative, Gram-negative bacterium, uncommon and difficult to treat in humans [45]. Enterococcus gallinarum was also never reported in hares or rabbits, also being of zoonotic importance [46,47]. The Vibrio vulnificus is a multi-host opportunistic bacteria [48] never reported in leporids. This bacteria leads to human mortality rates of $50 \%$ by sepsis and of $17 \%$ due to wound infection [49]. Besides infection is rare, this species is responsible for the most deaths caused by Vibrios [49]. The hare species are known for their reservoir potential for many other emerging or re-emerging pathogens of public health importance, namely Yersinia spp., Brucella spp., and Francisella tularensis (reviewed in [50]).

The following conclusions can be taken from this study: (i) the Iberian hare is not protected from mortality due to myxomatosis by Mixohipra-FSA and/or Mixohipra-H according to the dose used in domestic rabbits, (ii) it is possible to protect the Iberian hare from mortality due to myxomatosis using a higher dose of Mixohipra-FSA, (iii) the commercial vaccines Mixohipra-H and Nobivac Myxo-RHD PLUS protect the wild rabbit effectively against natural recombinant myxoma virus strains and (iv) the wild rabbit is susceptible to ha-MYXV directly isolated either from the wild rabbit or the Iberian hare.

This finding indicates that wild rabbits may contribute to the spread of ha-MYXV in hares. As two commercial myxoma vaccines (Mixohipra-FSA and Mixohipra-H) showed no 
efficacy in hares when using commercially recommended dosages, it is urgent to develop a robust vaccine for the Iberian hare or to investigate vaccine efficacy in hares of other commercial myxoma vaccines.

Author Contributions: Conceptualization, F.A.A.d.S., F.P. and M.D.D.; methodology, F.A.A.d.S., C.L.C., P.C.L.G.V., K.P.D., F.P. and M.D.D.; validation, F.A.A.d.S., K.P.D., F.P. and M.D.D.; formal analysis, F.A.A.d.S.; investigation, F.A.A.d.S., C.L.C., P.C.L.G.V., I.C.S., K.P.D., F.P. and M.D.D.; resources, F.A.A.d.S., P.C.L.G.V., H.A., S.S.R., M.C.P., K.P.D., F.P. and M.D.D.; data curation, F.A.A.d.S., C.L.C. and M.D.D.; writing - original draft preparation, F.A.A.d.S. and M.D.D.; writing-review and editing, C.L.C., P.C.L.G.V., H.A., S.S.R., M.C.P., I.C.S., K.P.D. and F.P.; visualization, F.A.A.d.S. and M.D.D.; supervision, M.C.P., F.P. and M.D.D.; project administration, F.P. and M.D.D.; funding acquisition, F.P. and M.D.D. All authors have read and agreed to the published version of the manuscript.

Funding: This study was funded by Fundo Florestal Permanente (Government of Portugal) in the scope of the Action Plan for the Control of Rabbit Viral Haemorrhagic Disease (+COELHO, Dispatch no. 4757/2017 of 31 May, No 2019014300001). This research was also funded by Fundação para a Ciência e Tecnologia (FCT), grant SFRH/BD/137067/2018 and Project UIDB/00276/2020 and by the Interdisciplinary Research Centre on Animal Health (Project CIISA-INOV 4/2021), Faculty of Veterinary Medicine, University of Lisbon (CIISA, FMV-UL) (Portugal). Franscisco Parra Laboratory was funded by grant AGL2017-83395-R from the Spanish Ministerio de Ciencia Innovación y Universidades, cofinanced by FEDER. KPD acknowledges funding from the Spanish Ministry for Science Innovation and Universities cofinanced by FEDER (reference number PID2020-120349RB-100). Funding bodies played no direct role in the design or conclusion of the study.

Institutional Review Board Statement: The animal study protocol was carried out in line with the measures identified in the National Plan for the control of rabbit haemorrhagic disease 2 (Dispatch 4757/2017, 31 May), operated through Project +Coelho 2, and approved by the National Authority for Animal Health (DGAV, Nr 79/ECVPT/20145) according to the National legislation (Decree-Law No. 113/2013, 7 August) after a positive declaration from the independent Advisory Body Responsible for Animal Welfare (ORBEA-INIAV, I.P.).

Informed Consent Statement: Not applicable.

Data Availability Statement: All data are presented in this study, there are no additional data.

Acknowledgments: We thank all the +Coelho team. We also thank the Faculdade de Medicina Veterinária da Universidade de Lisboa, the Escola Profissional ALSUD, the Escola Profissional Agrícola Fernando Barros Leal, Associação Galgueira e Lebreira do Norte, Associação de Galgueiros de Cuba João Grave and José Maria Rasquilha and respective teams, and all the dozens of private collaborators and friends, for collaboration in hare captures. We also thank the Faculty of Veterinary Medicine, particularly the Braço Forte Laboratory and the Hospital de São Bento, Lisbon, for the possibility of using their equipment in the analyses. We are thankful to Instituto da Conservação da Natureza e Florestas and Direção Geral de Agricultura e Veterinaria for all the help provided in these events, as well as to all the hunters who participated in fieldwork and sample collection. We also thank the OIE reference laboratory, Instituto Zooprofilattico Sperimentale della Lombardia ed Emilia Romagna, Brescia, Italy, for the cELISA analyses provided to this study.

Conflicts of Interest: The authors declare no conflict of interest.

\section{References}

1. Águeda-Pinto, A.; De Matos, A.L.; Abrantes, M.; Kraberger, S.; Risalde, M.A.; Gortázar, C.; McFadden, G.; Varsani, A.; Esteves, P.J. Genetic Characterization of a Recombinant Myxoma Virus in the Iberian Hare (Lepus granatensis). Viruses 2019, 11, 530. [CrossRef] [PubMed]

2. $\quad$ Dalton, K.P.; Martín, J.M.; Nicieza, I.; Podadera, A.; De Llano, D.; Casais, R.; Gimenez, S.; Badiola, I.; Agüero, M.; Duran, M.; et al. Myxoma virusjumps species to the Iberian hare. Transbound. Emerg. Dis. 2019, 66, 2218-2226. [CrossRef]

3. Carvalho, C.L.; Dos Santos, F.A.A.; Monteiro, M.; Carvalho, P.; Mendonça, P.; Duarte, M.D. First cases of myxomatosis in Iberian hares (Lepus granatensis) in Portugal. Vet. Rec. Case Rep. 2020, 8, e001044. [CrossRef]

4. Dos Santos, F.A.A.; Monteiro, M.; Pinto, A.; Carvalho, C.L.; Peleteiro, M.C.; Carvalho, P.; Mendonça, P.; Carvalho, T.; Duarte, M.D. First description of a herpesvirus infection in genus Lepus. PLoS ONE 2020, 15, e0231795. [CrossRef] [PubMed] 
5. Duarte, M.D.; Carvalho, C.L.; Dos Santos, F.A.; Monteiro, J.; Monteiro, M.; Carvalho, P.M.; Mendonça, P.; Santos, P.T.; Melo, P.C. The Health and Future of the Six Hare Species in Europe: A Closer Look at the Iberian Hare. In Lagomorpha Characteristics; IntechOpen: London, UK, 2020.

6. García-Bocanegra, I.; Camacho-Sillero, L.; Caballero-Gómez, J.; Agüero, M.; Gómez-Guillamón, F.; Ruiz-Casas, J.M.; Díaz-Cao, J.M.; García, E.; Ruano, M.J.; de la Haza, R. Monitoring of emerging myxoma virus epidemics in Iberian hares (Lepus granatensis) in Spain, 2018-2020. Transbound. Emerg. Dis. 2020, 68, 1275-1282. [CrossRef] [PubMed]

7. Dos Santos, F.A.; Carvalho, C.; Pinto, A.; Rai, R.; Monteiro, M.; Carvalho, P.; Mendonça, P.; Peleteiro, M.; Parra, F.; Duarte, M. Detection of recombinant Hare Myxoma Virus in wild rabbits (Oryctolagus cuniculus algirus). Viruses 2020, 12, 1127. [CrossRef] [PubMed]

8. dos Santos, F.A.A.; Carvalho, C.L.; Monteiro, M.; Carvalho, P.; Mendonça, P.; Peleteiro, M.D.C.; Duarte, M.D. Recombinant myxoma virus infection associated with high mortality in rabbit farming (Oryctolagus cuniculus). Transbound. Emerg. Dis. 2020, 68, 2616-2621. [CrossRef]

9. Villafuerte, R.; Delibes-Mateos, M. Oryctolagus cuniculus. IUCN Red List 2019, 8235. [CrossRef]

10. Soriguer, R.; Carro, F.; Lepus granatensis. IUCN Red List 2019: E.T41306A2953195. Available online: https://www.iucnredlist. org/species/41306/2953195 (accessed on 10 January 2022).

11. Delibes-Mateos, M.; Ferreras, P.; Villafuerte, R. European rabbit population trends and associated factors: A review of the situation in the Iberian Peninsula. Mammal Rev. 2009, 39, 124-140. [CrossRef]

12. Reemers, S.; Peeters, L.; Van Schijndel, J.; Bruton, B.; Sutton, D.; Van Der Waart, L.; Van De Zande, S. Novel Trivalent Vectored Vaccine for Control of Myxomatosis and Disease Caused by Classical and a New Genotype of Rabbit Haemorrhagic Disease Virus. Vaccines 2020, 8, 441. [CrossRef]

13. Dos Santos, F.A.A.; Carvalho, C.L.; Peleteiro, M.C.; Gabriel, S.I.; Patrício, R.; Carvalho, J.; Cunha, M.V.; Duarte, M. Blood collection from the external jugular vein of Oryctolagus cuniculus algirus sedated with midazolam: Live sampling of a subspecies at risk. Wildl. Biol. 2019, 2019, 1-10. [CrossRef]

14. Smallwood, S.E.; Rahman, M.M.; Smith, D.W.; McFadden, G. Myxoma Virus: Propagation, Purification, Quantification, and Storage. Curr. Protoc. Microbiol. 2010, 17, 14A.1.1-14A.1.20. [CrossRef] [PubMed]

15. Baer, A.; Kehn-Hall, K. Viral Concentration Determination Through Plaque Assays: Using Traditional and Novel Overlay Systems. J. Vis. Exp. 2014, e52065. [CrossRef] [PubMed]

16. dos Santos, F.A.A.; Carvalho, C.L.; Parra, F.; Dalton, K.P.; Peleteiro, M.C.; Duarte, M.D. A Quadruplex qPCR for Detection and Differentiation of Classic and Natural Recombinant Myxoma Virus Strains of Leporids. Int. J. Mol. Sci. 2021, 22, 12052. [CrossRef]

17. dos Santos, F.A.; Carvalho, C.; Peleteiro, M.; Parra, F.; Duarte, M. A Versatile qPCR for Diagnosis of Leporid Gammaherpesvirus 5 Using Evagreen ${ }^{\circledR}$ or Taqman ${ }^{\circledR}$ Technologies. Viruses 2021, 13, 715. [CrossRef] [PubMed]

18. Fenner, F.; Ratcliffe, F.N. Myxomatosis; Cambridge Universuty Press: London, UK, 1965.

19. García-Bocanegra, I.; Camacho-Sillero, L.; Risalde, M.A.; Dalton, K.P.; Caballero-Gómez, J.; Agüero, M.; Zorrilla, I.; GómezGuillamón, F. First outbreak of myxomatosis in Iberian hares (Lepus granatensis). Transbound. Emerg. Dis. 2019, 66, $2204-2208$. [CrossRef] [PubMed]

20. Duarte, M.; Carvalho, C.L.; Santos, F.A.; Monteiro, J.; Gomes, J.; Alves, P.C.; Esteves, P.J.; Abrantes, J.; Lopes, A.M.; Monterroso P.; et al. +Coelho2: Desenvolvimento e implementação de medidas práticas impulsionadoras da recuperação dos leporídeos silvestres em Portugal. In Relatório de Atividades na Época Venatória 2018-2019 e 2019-2020; Instituto Nacional de Investigação Agrária e Veterinária, I. P. (INIAV, I. P.): Oeiras, Portugal, 2020; Available online: https:/ / www.iniav.pt/images/Noticias/Coelho2 _Final-Report-web.pdf (accessed on 10 January 2022).

21. Guitton, J.-S.; Devillard, S.; Guénézan, M.; Fouchet, D.; Pontier, D.; Marchandeau, S. Vaccination of free-living juvenile wild rabbits (Oryctolagus cuniculus) against myxomatosis improved their survival. Prev. Veter- Med. 2008, 84, 1-10. [CrossRef]

22. Cabezas, S.; Calvete, C.; Moreno, S. Vaccination Success and Body Condition in the European Wild Rabbit: Applications for Conservation Strategies. J. Wildl. Manag. 2006, 70, 1125-1131. [CrossRef]

23. Ferreira, C.; Ramírez, E.; Castro, F.; Ferreras, P.; Alves, P.C.; Redpath, S.; Villafuerte, R. Field experimental vaccination campaigns against myxomatosis and their effectiveness in the wild. Vaccine 2009, 27, 6998-7002. [CrossRef]

24. Marlier, D. Vaccination strategies against myxomavirus infections: Are we really doing the best? Tijdschr. Diergeneeskd. 2010, 135, 194-198.

25. Kerr, P.J.; Merchant, J.C.; Silvers, L.; Hood, G.M.; Robinson, A.J. Monitoring the spread of myxoma virus in rabbit Oryctolagus cuniculus populations on the southern tablelands of New South Wales, Australia. II. Selection of a strain of virus for release. Epidemiology Infect. 2003, 130, 123-133. [CrossRef] [PubMed]

26. Ashton, L.V.; Quackenbush, S.L.; Castle, J.; Wilson, G.; McCoy, J.; Jordan, M.; MacNeill, A.L. Recombinant Myxoma Virus Expressing Walleye Dermal Sarcoma Virus or fC Is Attenuated in Rabbits. Viruses 2020, 12, 517. [CrossRef] [PubMed]

27. Dalton, K.; Nicieza, I.; de Llano, D.; Gullón, J.; Inza, M.; Petralanda, M.; Arroita, Z.; Parra, F. Vaccine breaks: Outbreaks of myxomatosis on Spanish commercial rabbit farms. Veter- Microbiol. 2015, 178, 208-216. [CrossRef] [PubMed]

28. Manev, I.; Genova, K.; Lavazza, A.; Capucci, L. Humoral immune response to different routes of myxomatosis vaccine application. World Rabbit Sci. 2018, 26, 149-154. [CrossRef]

29. Levin, C.; Perrin, H.; Combadiere, B. Tailored immunity by skin antigen-presenting cells. Hum. Vaccines Immunother. 2014, 11, 27-36. [CrossRef] 
30. Kim, Y.C.; Jarrahian, C.; Zehrung, D.; Mitragotri, S.; Prausnitz, M.R. Delivery Systems for Intradermal Vaccination. Intradermal Immun. 2011, 351, 77-112. [CrossRef]

31. Psikal, I.; Smid, B.; Rodak, L.; Valicek, L.; Bendova, J. Atypical myxomatosis-virus isolation, experimental infection of rabbits and restriction endonuclease analysis of the isolate. J. Veter-Med. Ser. B 2003, 50, 259-264. [CrossRef]

32. Marshall, I.D.; Fenner, F. Studies in the epidemiology of infectious myxomatosis of rabbits: VII. The virulence of strains of myxoma virus recovered from Australian wild rabbits between 1951 and 1959. J. Hyg. 1960, 58, 485-488. [CrossRef]

33. Kerr, P.; Perkins, H.; Inglis, B.; Stagg, R.; McLaughlin, E.; Collins, S.; Van Leeuwen, B. Expression of rabbit IL-4 by recombinant myxoma viruses enhances virulence and overcomes genetic resistance to myxomatosis. Virology 2004, 324, 117-128. [CrossRef]

34. Kappler-Gratias, S.; Bucher, L.; Top, S.; Quentin-Froignant, C.; Desbois, N.; Bertagnoli, S.; Louison, M.; Monge, E.; BousquetMelou, A.; Lacroix, M.; et al. Antipoxvirus Activity Evaluation of Optimized Corroles Based on Development of Autofluorescent ANCHOR Myxoma Virus. ACS Infect. Dis. 2021, 7, 2370-2382. [CrossRef]

35. Boutard, B.; Vankerckhove, S.; Markine-Goriaynoff, N.; Sarlet, M.; Desmecht, D.; McFadden, G.; Vanderplasschen, A.; Gillet, L. The $\alpha 2,3-$ Sialyltransferase Encoded by Myxoma Virus Is a Virulence Factor that Contributes to Immunosuppression. PLoS ONE 2015, 10, e0118806. [CrossRef] [PubMed]

36. Bárcena, J.; Morales, N.; Boga, A.; Parra, F.; Sa, M.; Lucientes, J.; Page, A.; Blasco, R.; Torres, J.M. Horizontal Transmissible Protection against Myxomatosis and Rabbit Hemorrhagic Disease by Using a Recombinant Myxoma Virus. J. Virol. 2000, 74, 1114-1123. [CrossRef] [PubMed]

37. OIE. Terrestrial Manual Myxomatosis. In Lagomorpha; OIE: Paris, France, 2018; pp. 1371-1388.

38. Kerr, P.J.; Cattadori, I.M.; Rogers, M.B.; Fitch, A.; Geber, A.; Liu, J.; Sim, D.G.; Boag, B.; Eden, J.-S.; Ghedin, E.; et al. Genomic and phenotypic characterization of myxoma virus from Great Britain reveals multiple evolutionary pathways distinct from those in Australia. PLoS Pathog. 2017, 13, e1006252. [CrossRef] [PubMed]

39. Spibey, N.; McCabe, V.J.; Greenwood, N.M.; Jack, S.C.; Sutton, D.; van der Waart, L. Novel bivalent vectored vaccine for control of myxomatosis and rabbit haemorrhagic disease. Veter-Rec. 2012, 170, 309. [CrossRef]

40. Guerin, J.-L.; Gelfi, J.; Camus, C.; Delverdier, M.; Whisstock, J.; Amardeihl, M.-F.; Py, R.; Bertagnoli, S.; Messud-Petit, F. Characterization and functional analysis of Serp3: A novel myxoma virus-encoded serpin involved in virulence. J. Gen. Virol. 2001, 82, 1407-1417. [CrossRef]

41. Fenner, B.Y.F.; Marshall, I.D. A comparison of the virulence for european rabbits (Oryctolagus cuniculus) of strains of Myxoma virus recovered in the field in Australi, Europe and America. J. Hyg. 1957, 55, 149-191. [CrossRef]

42. Fenner, F.; Woodroofe, G.M. Changes in the virulence and antigenic structure of strains of myxoma virus recovered from Australian wild rabbits between 1950 and 1964. Aust. J. Exp. Biol. Med. Sci. 1965, 43, 359-370. [CrossRef]

43. Jeklova, E.; Leva, L.; Matiasovic, J.; Kovarcik, K.; Kudlackova, H.; Nevorankova, Z.; Psikal, I.; Faldyna, M. Characterisation of immunosuppression in rabbits after infection with myxoma virus. Veter- Microbiol. 2008, 129, 117-130. [CrossRef]

44. Sousa, M.; Silva, V.; Silva, A.; Silva, N.; Ribeiro, J.; Tejedor-Junco, M.T.; Capita, R.; Chenouf, N.S.; Alonso-Calleja, C.; Rodrigues, T.M.; et al. Staphylococci among Wild European Rabbits from the Azores: A Potential Zoonotic Issue? J. Food Prot. 2020, 83, 1110-1114. [CrossRef]

45. Brooke, J.S. Stenotrophomonas maltophilia: An emerging global opportunistic pathogen. Clin. Microbiol. Rev. 2012, $25,2-41$. [CrossRef]

46. Barber, G.R.; Lauretta, J.; Saez, R. A Febrile Neutropenic Patient with Enterococcus gallinarum Sepsis Treated with Daptomycin and Gentamicin. Pharmacother. J. Hum. Pharmacol. Drug Ther. 2007, 27, 927-932. [CrossRef] [PubMed]

47. Li, X.; Fan, S.; Lin, X.; Liu, L.; Zheng, J.; Zhou, X.; Heep, A. The first case report of Enterococcus gallinarum meningitis in neonate. Medicine 2018, 97, e9875. [CrossRef] [PubMed]

48. Roig, F.J.; González-Candelas, F.; Sanjuan, E.; Fouz, B.; Feil, E.J.; Llorens, C.; Baker-Austin, C.; Oliver, J.D.; Danin-Poleg, Y.; Gibas, C.J.; et al. Phylogeny of Vibrio vulnificus from the Analysis of the Core-Genome: Implications for Intra-Species Taxonomy. Front. Microbiol. 2018, 8, 2613. [CrossRef] [PubMed]

49. Horseman, M.A.; Surani, S. A comprehensive review of Vibrio vulnificus: An important cause of severe sepsis and skin and soft-tissue infection. Int. J. Infect. Dis. 2011, 15, e157-e166. [CrossRef] [PubMed]

50. Tsokana, C.N.; Sokos, C.; Giannakopoulos, A.; Birtsas, P.; Valiakos, G.; Spyrou, V.; Athanasiou, L.V.; Burriel, A.R.; Billinis, C. European Brown hare (Lepus europaeus) as a source of emerging and re-emerging pathogens of Public Health importance: A review. Veter-Med. Sci. 2020, 6, 550-564. [CrossRef] [PubMed] 